\title{
Renal effects of growth hormone in health and in kidney disease
}

\author{
Dieter Haffner $^{1,2}$ (D) Andrea Grund ${ }^{1,2}$ • Maren Leifheit-Nestler ${ }^{1,2}$ \\ Received: 23 March 2021 / Accepted: 27 April 2021 / Published online: 18 June 2021 \\ (C) The Author(s) 2021
}

\begin{abstract}
Growth hormone (GH) and its mediator insulin-like growth factor-1 (IGF-1) have manifold effects on the kidneys. GH and IGF receptors are abundantly expressed in the kidney, including the glomerular and tubular cells. GH can act either directly on the kidneys or via circulating or paracrine-synthesized IGF-1. The GH/IGF-1 system regulates glomerular hemodynamics, renal gluconeogenesis, tubular sodium and water, phosphate, and calcium handling, as well as renal synthesis of $1,25(\mathrm{OH})_{2}$ vitamin $\mathrm{D}_{3}$ and the antiaging hormone Klotho. The latter also acts as a coreceptor of the phosphaturic hormone fibroblast-growth factor 23 in the proximal tubule. Recombinant human $\mathrm{GH}(\mathrm{rhGH})$ is widely used in the treatment of short stature in children, including those with chronic kidney disease (CKD). Animal studies and observations in acromegalic patients demonstrate that GH-excess can have deleterious effects on kidney health, including glomerular hyperfiltration, renal hypertrophy, and glomerulosclerosis. In addition, elevated GH in patients with poorly controlled type 1 diabetes mellitus was thought to induce podocyte injury and thereby contribute to the development of diabetic nephropathy. This manuscript gives an overview of the physiological actions of GH/IGF-1 on the kidneys and the multiple alterations of the GH/IGF-1 system and its consequences in patients with acromegaly, $\mathrm{CKD}$, nephrotic syndrome, and type 1 diabetes mellitus. Finally, the impact of short- and long-term treatment with rhGH/rhIGF-1 on kidney function in patients with kidney diseases will be discussed.
\end{abstract}

Keywords Growth hormone $\cdot$ IGF-1 $\cdot$ Klotho $\cdot$ Hypertrophy $\cdot$ Children $\cdot$ Chronic kidney disease $\cdot$ Nephrotic syndrome $\cdot$ Diabetic nephropathy

\section{Introduction}

Growth hormone $(\mathrm{GH})$ is widely used for the treatment of short stature in children, including those suffering from chronic kidney disease (CKD). The GH / insulin-like growth factor1 (IGF-1) system has profound effects on the kidneys, including glomerular and tubular function, as well as the synthesis of $1,25(\mathrm{OH})_{2}$ vitamin $\mathrm{D}_{3}$ and the antiaging hormone Klotho (Fig. 1). Animal studies and observations in acromegalic patients have demonstrated that GH-excess can impact on kidney health, including glomerular hyperfiltration and hypertrophy and glomerulosclerosis. In addition, elevated GH in

Dieter Haffner

Haffner.Dieter@mh-hannover.de

1 Department of Pediatric Kidney, Liver and Metabolic Diseases, Pediatric Research Center, Hannover Medical School, Carl-Neuberg-Str. 1, 30625 Hannover, Germany

2 Pediatric Research Center, Hannover Medical School, Carl-Neuberg-Str. 1, 30625 Hannover, Germany patients with poorly controlled type 1 diabetes mellitus was shown to induce podocyte injury and thereby may contribute to diabetic nephropathy. This manuscript gives an overview of the physiological actions of GH and IGF-1 on the kidneys and summarizes the current knowledge of their impact on kidney health in subjects with normal and impaired kidney function, including acute kidney injury (AKI), CKD and nephrotic syndrome. We will update and expand on previous, excellent reviews on this topic published over the last three decades [1-5].

\section{Physiology of GH}

\section{GH and IGFs}

Growth hormone is a $22-\mathrm{kDa}$ protein, which is secreted from the anterior pituitary gland in a pulsatile, predominantly nocturnal fashion, with highest secretion rates during puberty [6]. In the circulation, $\mathrm{GH}$ is bound to the high affinity $\mathrm{GH}$ binding protein (GHBP), which is generated by proteolytic cleavage of 


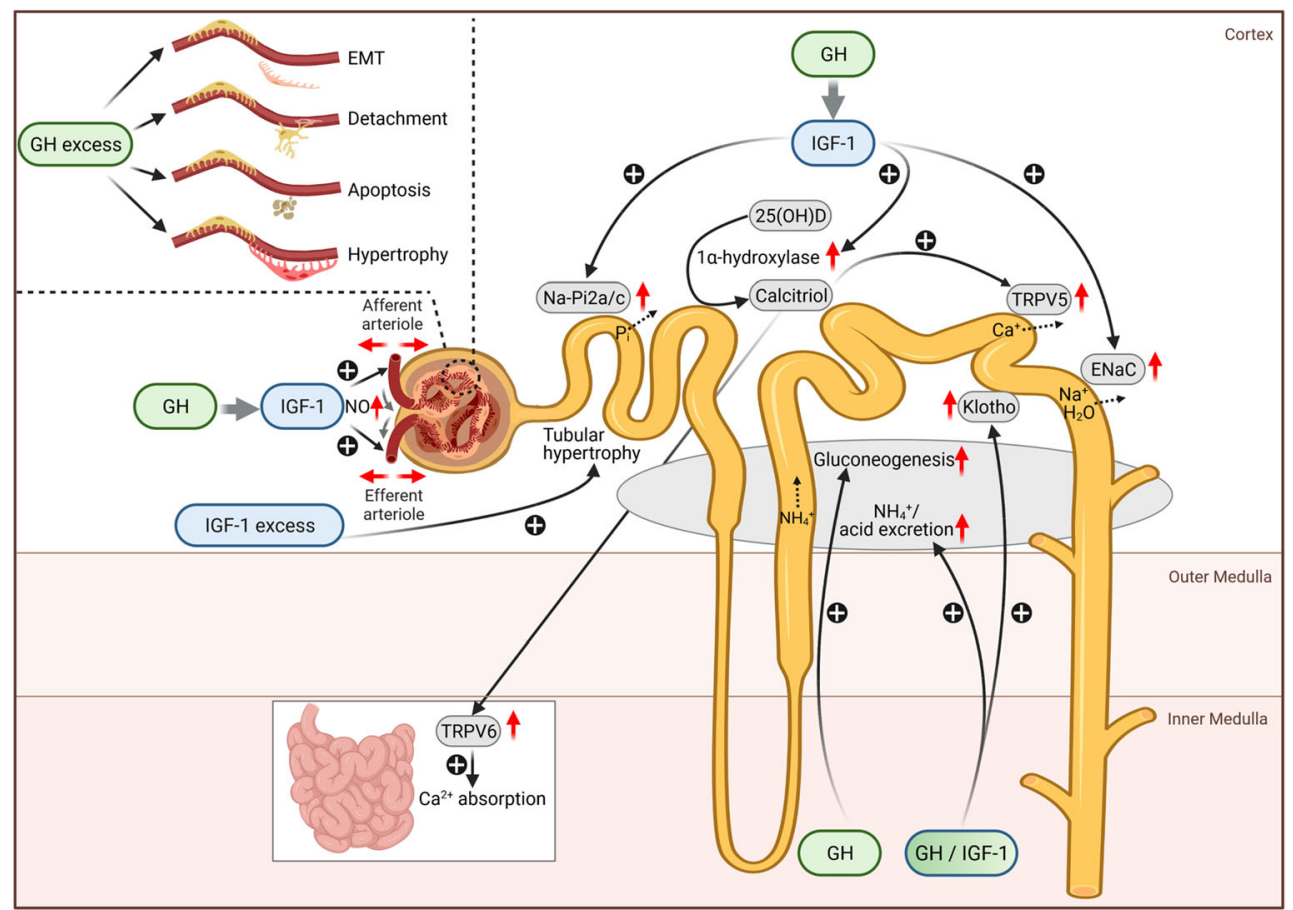

Fig. 1 Physiological and pathophysiological actions of growth hormone and its mediator insulin-like growth factor-1 (IGF-1) on the kidneys: GH and IGF-1 receptors (GHR/IGF-1R) are widely expressed in the glomerular and tubular cells. GH can act on the kidneys, either directly via activation of the GHR/Janus kinase-2 (JAK2)-signal transducer and activator of transcription 5 (STAT5) and ERK1/2 pathways, or indirectly via circulating or paracrine-synthesized IGF-1 by activating IGF-1R. Most of the glomerular and tubular effects of GH are mediated by IGF-1 and include the following: (1) dilation of the afferent and efferent arterioles via increased synthesis of the endogenous vasodilator nitric oxide (NO), resulting in enhanced glomerular filtration rate and renal plasma flow; (2) stimulation of phosphate $(\mathrm{Pi})$ reabsorption in the proximal tubules via upregulation of the sodium-phosphate transporters $(\mathrm{Na}-\mathrm{Pi} 2 \mathrm{a} / 2 \mathrm{c}$; (3) stimulation of sodium $\left(\mathrm{Na}^{+}\right)$and water $\left(\mathrm{H}_{2} \mathrm{O}\right)$ reabsorption in the distal nephron via up-regulation of the epithelial sodium channel ( $\mathrm{ENaC})$; and (4) stimulation of the $1 \alpha$-hydroxylase and thereby, calcitriol synthesis in the proximal tubule, with subsequent increases in calcium $\left(\mathrm{Ca}^{+}\right)$absorption via up-regulation of the epithelial calcium channels TRPV6 and TRPV5 in the intestine and distal renal tubule, respectively. Some GH effects may also be mediated by IGF-1, including stimulation of (1) net acid secretion via increased ammonia $\left(\mathrm{NH}_{4}{ }^{+}\right)$production in the proximal tubule and a $\mathrm{Na}^{+}$-dependent mechanism in the distal tubule and (2) renal Klotho synthesis in the distal renal tubule. GH was shown to directly enhance renal gluconeogenesis in proximal tubular cells. In states of GH excess, GH can directly induce glomerulosclerosis and podocyte injury, characterized by podocyte hypertrophy, apoptosis, dedifferentiation of podocytes (epithelial-mesenchymal transition, EMT), and/or cross-linking of the basement membrane resulting in increased podocyte permeability to albumin and detachment of podocytes from the glomerular basement membrane. By contrast, IGF-1 excess results in tubular hypertrophy only. The kidneys of patients with chronic kidney disease (CKD) are protected from the potentially negative effects of long-term GH-treatment on the glomerulus, likely due to the CKD-associated GH insensitivity of the kidneys and/or the much lower GH exposure in GH-treated patients, compared to those with the abovementioned conditions.

IGF-1 or -2, forming a high-molecular weight ternary complex of approx. $150 \mathrm{kDa}$ which functions as a reservoir of IGFs, thereby keeping the serum concentrations of free IGFs constant. The second and third most abundant IGFBPs are IGFBP-2 (32 kDa) and IGBP-1 (28 kDa), which can also bind IGF-1 and IGF-2, and are thought to modulate IGF actions by competing with the IGF receptors.

GH and IGF-1 act synergistically with respect to growth and the kidneys and antagonistically on glucose metabolism, i.e., GH stimulates glucose synthesis and concentrations, whereas IGF-1 decreases serum glucose levels. After binding to the GHR, the intracellular Janus kinase-2 (JAK2)-signal transducer and activator of transcription 5 (STAT5) and ERK1/2 pathways are activated [8]. In addition, proteins of the suppressor cytokine signaling (SOCS) family are synthesized, acting as a negative feedback mechanism. IGF-1 exerts 
its actions on a cellular level via the IGF-1 receptor (IGF-1R) which results in activation of several intracellular pathways, including the ERK1/2 and phosphatidylinositol 3-kinase/ AKT pathways.

\section{GH and IGF signaling in the kidney}

\section{GH receptor}

The GHR is expressed in most tissues, including the kidney. In 1989 GHR mRNA in the rat was already shown to be mainly expressed in the straight proximal tubules from embryonic day 20 onwards, increasing until postnatal day 40 and with constant levels thereafter [9]. A much more widespread expression of GHR was revealed by immunostaining in human fetal kidneys, including all nephron segments. By contrast, only a very weak signal was detected in the glomeruli of fetal but not in adult kidneys [10]. The latter suggests that $\mathrm{GH}$ may be involved in glomerular morphogenesis. Recent investigations in rodents and humans confirmed GHR expression in all tubular segments and this extended to the predominant glomerular cell types, i.e., mesangial cells and podocytes, when using quantitative real-time RT-PCR techniques [11-14]. The concept of direct GH action on glomerular cells is supported by studies in transgenic mice overexpressing human or bovine GH showing progressive glomerulosclerosis, whereas IGF-1 overexpressing mice lack glomerular changes [14]. Several studies confirmed the integrity of GH-signaling via GHR/JAK2/STAT5 pathway in the kidney by using renal cell lines $[11,12]$.

\section{Insulin-like growth factor-1 and 2}

Renal IGF-1 not only derives from the circulation (mainly synthesized in the liver) but is also locally produced in the kidney [15]. It exerts its paracrine and autocrine effects under the regulation of circulating GH [16]. While IGF-1 was shown to be expressed in all renal cells during fetal life, a drastic decrease was noted after birth. After birth, IGF-1 synthesis is restricted to the medullary, thick ascending limb of Henle's loop, collecting ducts, and peritubular capillaries of the outer medulla and inner cortex [10,17-19]. The distribution of IGF1 and its availability in kidney tissues is under the regulation of six high-affinity IGF binding proteins (IGFBPs) [20]. IGF2 is also highly expressed in the fetal kidney and plays an important role during kidney development, whereas its role after birth needs to be clarified [21].

\section{IGF-1 receptor}

IGF-1 receptor (IGF-1R) was shown to be expressed in both rodents and humans throughout the nephron, including the glomeruli $[10,19,22-24]$. Whereas initial studies suggest that its expression in the proximal tubules is very low, recent studies using microdissected, freshly-isolated, murine, nephronic segments demonstrated the highest IGF-1R mRNA expression in proximal tubules along the nephron [11]. The functional integrity of IGF-1-induced IGF-1R signaling in the kidney was demonstrated by using renal cell lines $[11,25,26]$.

\section{GH and kidney development}

GH knockout mice $\left(\mathrm{GH}^{--}\right)$show reduced kidney weight compared to wild-type mice, even after correction for reduced body weight [27]. Unfortunately, studies on renal histology and glomerular function in $\mathrm{GH}^{-/ /}$mice are lacking. In contrast to $\mathrm{GH}^{-/}$mice, IGF-1/- mice show a proportional reduction in kidney weight when compared to wild-type mice. However, histological studies revealed slightly smaller glomeruli and a $20 \%$ reduction in the number of glomeruli in IGF- $1^{-/}$mice compared to controls [3]. The contribution of circulating versus locally produced IGF-1 in kidney development was investigated using a hepatic specific JAK2 knockout in mice [28]. As expected, hepatic specific JAK2 $2^{-/}$mice showed no hepatic IGF-1 synthesis and markedly reduced IGF-1 serum concentrations compared to wild-type mice. In addition, kidney weight was markedly reduced in GH-treated and untreated $\mathrm{JAK} 2^{-/}$mice compared to controls, indicating the importance of circulating IGF-1 in kidney growth, whereas locally produced IGF-1 seems not to have a significant impact on kidney growth.

\section{GH and renal hemodynamics}

Corvilain et al. demonstrated in their seminal study that exogenous GH, i.e., GH-containing pituitary extracts, increases glomerular filtration rate (GFR) in healthy subjects [29]. This could be confirmed by using daily subcutaneous injections of recombinant human $\mathrm{GH}$ ( $\mathrm{rhGH}$ ), resulting in increases ranging from 11-18\% compared to baseline after three and up to 7 days of treatment [30-33]. Equally, (rh)GH was shown to increase renal plasma flow (RPF) in healthy subjects by approx. $25 \%$ after 3 and up to 7 days of treatment [30-32, 34]. However, GH-infusion in healthy subjects had no effects on GFR or RPF over a 2-h observation period [35]. Serial GFR and RPF measurements in a GH-deficient adult revealed a delayed rhGH-induced rise in GFR and RPF, starting $24 \mathrm{~h}$ after injection, in parallel with the concomitant rise in IGF-1 serum concentrations [31]. Similar findings were later seen in healthy subjects [30]. Taken together, these studies suggest that the GH-induced rise in GFR and RPF is mediated by IGF-1, rather than due to the direct effects of GH on the glomerulus [2]. Subsequent studies in healthy subjects and rodents revealed that application of IGF-1 leads to an acute rise ( $<20 \mathrm{~min}$ ) in GFR and RPF of approximately $20-30 \%$, compared to baseline values [36-38]. These effects were 
maintained during a 7-day IGF-1 treatment in rats [39]. Using micropuncture studies it was shown that these effects are mainly due to dilation of both the efferent and afferent arterioles and resulted in reduction of renal vascular resistance, as illustrated in Fig. 1 [40, 41]. The effects of GH on GFR and RPF in humans could be blunted by coadministration of cyclooxygenase inhibitors, suggesting that they depend on the availability of vasodilating prostaglandins [42]. Also, the vasodilatory effects of IGF-1 on renal juxtamedullary microvasculature could be completely blocked by pretreatment with the cyclooxygenase inhibitor indomethacin [41]. Moreover, there is evidence that the vasodilatory effects of IGF-1 are mediated by nitric oxide (NO) and cyclic GMP (cGMP). Studies in cultured, vascular, endothelial cells showed that IGF-1 induces NO release [43]. Administration of IGF-1 in rats increases urinary excretion of cGMP which mediates the intracellular effects of NO on smooth muscle cells [2]. More importantly, the acute IGF-1-induced rise in GFR and RPF in rodents is blunted by coadministration of an NO synthase inhibitor [42]. Taken together, the effects of IGF-1 on renal vasodilation depend on the synthesis of endogenous vasodilators including $\mathrm{NO}$ and prostaglandins.

Interestingly, $\mathrm{GH}$ also has hemodynamic effects in nonrenal vascular beds. A 7-day treatment with rhGH significantly increased microvascular blood flow, as assessed by nailfold capillaroscopy and leg-strain gauge plethysmography in healthy subjects [44]. This was associated with a reduction of total vascular resistance, and increased heart rate and cardiac index. These effects are also most likely mediated by IGF-1.

\section{GH and glomerular cells}

Reddy et al. identified the glomerular podocyte as a target for $\mathrm{GH}$ action by demonstrating that cultured murine podocytes and kidney glomeruli express GHR and treatment with rhGH, of both murine and human podocytes, results in activation of the GHR/JAK2/STAT5 and ERK1/2 pathways in these cells [12]. In addition, treatment with rhGH stimulated the focal adhesion kinase, increased reactive oxygen species and reorganization of the podocyte actin cytoskeleton [12]. The same group also demonstrated that zinc finger E-box-binding, homebox 2 (ZEB2), is upregulated in immortalized human podocytes by rhGH-treatment in a dose- and time-dependent manner [45]. The GH-induced increase in ZEB2 expression caused a downregulation of E- and P-cadherins. In addition, the GH-induced increase in podocyte permeability to albumin in a paracellular albumin influx assay could be completely blocked by a ZEB2 knockdown, suggesting that exposure to high levels of GH may induce glomerular albuminuria, due to increased podocyte permeability (vide infra) [45]. However, both GH and IGF-1 were also shown to have positive effects on the glomerulus. Epithelial-to-mesenchymal-transition, which is an important component in the development of glomerulosclerosis, could be completely reversed by administration of rhGH in a model of hyperhomocystinemiainduced podocyte dysfunction [46]. Treatment with IGF-1 resulted in enhanced cell migration and differentiation and, thereby, ameliorated podocyte apoptosis induced by cytokine or high glucose concentration [47]. Therefore, the physiological role of GH and IGF-1 on glomerular function is still unclear.

\section{GH and tubular function}

\section{Phosphate}

Phosphate hemostasis is highly regulated by the kidneys. Under normal conditions, approx. $80 \%$ of filtered phosphate is reabsorbed in the renal proximal tubules by sodiumphosphate transporters (Na-Pi2a and 2c) under the regulation of hormones, including parathyroid hormone (PTH), fibroblast-growth factor 23 (FGF23), and IGF-1 [48]. The physiological increase in renal phosphate handling occurring during growth in children is attributed to increasing levels of IGF-1. Administration of GH increases the maximum tubular phosphate reabsorption rate per GFR (TmP/GFR) in humans and canines, resulting in concomitant increases in serum phosphate levels $[29,49,50]$. Similar to the GH actions on GFR, these effects seem to be delayed $(>2 \mathrm{~h})$ and most likely mediated by IGF-1 (Fig. 1). In vitro perfusion studies, using isolated proximal convoluted tubules and in vitro studies using $\mathrm{OK}$ cells, showed that IGF-1 directly increases phosphate reabsorption via increase of protein levels of Na-Pi2a at the plasma membrane, which could be completely blocked by an antiIGF-1R antibody [51-53].

\section{Sodium and water}

The sodium-retaining properties of GH, which are accompanied by an increased extracellular volume, were initially shown by Beck et al. using GH-containing pituitary extracts in healthy subjects and later confirmed in various studies using rhGH in humans and rodents [54-56]. In a randomized, 8 -week trial GH significantly increased extracellular water mass in male and female athletes by $10.2 \%(1.8 \mathrm{~kg})$ and $7.9 \%(1.2 \mathrm{~kg})$ compared to controls, which was significantly associated with more frequent reports of swelling [54]. Initial studies suggest that the GH-induced sodium and water retention is mediated by the renin-angiotensin-aldosterone system (RAAS), which could not be confirmed [57, 58]. IGF-1 acts as an antinatriuretic in healthy subjects and in children with GHR-defects, suggesting that its sodium-retaining properties may be at least partly mediated by IGF-1 $[59,60]$. The sodium-retention properties of IGF-1 can be blocked by amiloride, suggesting the involvement of the epithelial sodium 
channel $(\mathrm{ENaC})$ [61]. Indeed, recent elegant studies in humans and collecting duct cell lines showed that IGF-1 regulates sodium reabsorption in the distal nephron by activation of the IGF-1R, which results in upregulation of the $\mathrm{ENaC}[25$, 26]. These effects were shown to be independent of aldosterone, a known regulator of $\mathrm{ENaC}$-dependent sodium reabsorption $[25,26]$. This concept is also supported by studies in rats with GH-producing tumors showing increased natriuretic response when treated with amiloride, which is a selective $\mathrm{ENaC}$ blocker, whereas natriuretic response was decreased by furosemide, which acts on the loop of Henle (Fig. 1) [11]. Also, an increased natriuretic response to amiloride, but not to furosemide, was recently demonstrated in acromegalic patients, which further supports the concept that $\mathrm{GH}$ increases $\mathrm{ENaC}$ activity [62].

Viengchareun et al. proposed that GH may also directly regulate $\mathrm{ENaC}$ by stimulating the transcription of the $\alpha$ subunit of ENaC via the JAK2/STAT5 and MAPK pathways [63]. This was based on in vitro studies showing that GH can increase binding of phospho-STAT5 to the response element of the promotor of the SCNNIA gene encoding the $\alpha \mathrm{ENaC}$ subunit [63]. Thus, GH and IGF-1 may act synergistically to stimulate renal sodium reabsorption. However, direct proof that $\mathrm{GH}$ activates $\mathrm{ENaC}$-dependent sodium transport in distal tubules is lacking. Taken together, studies in healthy subjects suggest that pharmacological doses of GH and IGF-1 promote sodium retention with consecutive edema formation, which is transient in most subjects.

\section{Calcium and vitamin D metabolism}

Calcium hemostasis is mainly regulated by activated vitamin $\mathrm{D}$ (calcitriol) and PTH. Both, GH and IGF-1 lead to a positive calcium balance via their effects on vitamin D metabolism, which is especially important in children due to the demands of their growing skeleton, whereas their effects on PTH are unclear. GH stimulates renal calcitriol synthesis in humans and rodents, which was shown to be mediated by IGF-1 via stimulation of $1 \alpha$-hydroxylase in the proximal tubule (Fig. 1) [64-68]. Subsequently, calcitriol increases intestinal calcium absorption by stimulation of the epithelial calcium channel TRPV6 [69, 70] and stimulates renal calcium absorption in the distal renal tubule by upregulating the expression of the epithelial calcium channel TRPV5 [71]. The latter is supported by studies in acromegalic patients showing enhanced renal calcium absorption in the distal tubule, but not in Henle's loop [72]. Both mechanisms promote a positive calcium balance [73].

\section{Acid-base hemostasis}

Metabolic acidosis is rarely reported in children with GHdeficiency [74]. However, retrospective biochemical analysis in short children with GH-deficiency and children with other causes of growth failure, revealed significant lower mean serum bicarbonate concentrations in patients with $\mathrm{GH}$ deficiency [74]. In addition, a significant increase was noted in GH-deficient children during treatment with $\mathrm{rhGH}$, suggesting that GH and/or IGF-1 affect acid-base hemostasis. This is further supported by studies in hypophysectomized rats demonstrating metabolic acidosis, which can be corrected by GH treatment [75]. GH stimulates the production of ammonia in canine renal proximal tubule segments, suggesting that it may be a regulator of net acid secretion [76]. In addition, studies in humans indicate that GH also stimulates distal tubular $\mathrm{Na}^{+}$absorption which may be essential for the GHinduced distal nephron proton secretion (Fig. 1) [77]. Treatment with $\mathrm{GH}$ in humans with $\mathrm{NH}_{4} \mathrm{Cl}$-induced chronic metabolic acidosis restored plasma bicarbonate levels, which was associated with an increase in renal net acid secretion. However, these effects were completely blunted in $\mathrm{NaCl}-$ restricted subjects, despite GH-stimulated renal ammonia production as suggested by increases in urine $\mathrm{pH}$, and could be restored after changing back to a normal NaCL diet. Thus, the effects of GH on net acid secretion are dependent on the availability of a surfeit of a $\mathrm{Na}^{+}$tubular reabsorption. Taken together, the current available data suggest that GH and/or IGF-1 regulate acid-base hemostasis by stimulation of ammonia production in the proximal renal tubule and/or by a Na-dependent mechanism in the collecting duct, resulting in enhanced proton secretion.

\section{Gluconeogenesis}

Under euglycemic conditions, gluconeogenesis in proximal tubular cells is almost exclusively used by the kidney itself, mainly by medullary cells. However, during fasting conditions gluconeogenesis by the kidneys amounts to up to $50 \%$ of endogenous glucose production in order to maintain euglycemia [78]. During the fasting state, GH-secretion from the pituitary glands is markedly stimulated, whereas insulin and IGF-1 secretion is reduced. GH was shown to enhance renal gluconeogenesis in proximal tubular cells via activation of the GHR, independent of IGF-1 [10, 79]. Thus, in the fasting state $\mathrm{GH}$-induced renal gluconeogenesis is essential in order to maintain euglycemia (Fig. 1).

\section{Klotho}

The antiaging protein $\alpha$-Klotho is a $130 \mathrm{kDa}$ membranebound protein mainly synthesized in the kidneys and acting as a coreceptor for FGF23, thereby mediating its renal effects with respect to phosphate handling and calcitriol synthesis [80]. FGF23 acts in opposition to GH by increasing phosphaturia via suppression of $\mathrm{Na}-\mathrm{Pi} 2 \mathrm{a}$ and $2 \mathrm{c}$ expression in proximal tubules and decreasing renal calcitriol synthesis, whereas it shares its calcium-sparing effects by enhancing renal 
calcium reabsorption in the distal tubule [81]. Klotho is mainly expressed in the distal renal tubule and, to a lesser extent, in proximal tubules. It also exists in a soluble form (sKlotho) which is generated by cleavage of the extracellular domain of $\alpha$-Klotho, which circulates in the blood and also exerts systemic effects, including cardioprotective properties, which are still poorly understood $[80,82]$. In general, the amount of circulating sKlotho is correlated to the expression of membrane-bound $\alpha$-Klotho in the kidneys and, thereby, serves as an indicator of renal $\alpha$-Klotho expression [80].

Treatment with rhGH has been shown to increase the circulating levels of sKlotho in healthy subjects and in adults with stage $3 \mathrm{CKD}$, as well as in patients with GH-deficiency [83, 84]. Similarly, rhGH-treatment was associated with higher sKlotho levels in children with CKD, irrespective of the underlying kidney disease [85]. Upregulation of sKlotho may possibly exert positive cardiac and vascular effects through enhanced FGF23-mediated NO release from small vessels, resulting in improved endothelial function (vide supra) [86]. These GH actions may also be partly mediated by IGF-1, as suggested by the findings of positive associations with sKlotho levels in GH-sufficient and GH-deficient pediatric patients with short stature $[87,88]$.

\section{Pathophysiology of GH}

\section{GH hypersecretion}

The effects of GH hypersecretion on the kidneys have been extensively evaluated in acromegalic patients and animals chronically exposed to excessive GH and IGF-1 levels, and in transgenic mice with GH or IGF-1 overexpression (Fig. 1) [89].

\section{Acromegaly}

Kidney morphology Acromegaly is associated with renal hypertrophy in humans and rodents [1]. In a case control study, kidney length assessed by kidney ultrasound was significantly increased by approx. $5 \mathrm{~cm}(55 \%)$ and $2 \mathrm{~cm}(20 \%)$ in active and controlled acromegalic patients, respectively [90]. Kidney size rapidly normalizes within 3 to 6 months in acromegalic patients undergoing transsphenoidal surgery [91]. Systematic studies on renal histology in acromegalic patients are lacking. Rare cases, where acromegalic patients underwent kidney biopsy due to nephrotic syndrome or persistent proteinuria, revealed focal segmental glomerulosclerosis $[92,93]$. In one acromegalic patient presenting with nephrotic range proteinuria and focal segmental glomerulosclerosis on kidney biopsy, proteinuria quickly normalized after tumor removal but returned 4 months later, but responded to prednisolone treatment [94]. Only moderate or nonglomerular hypertrophy was noted in acromegalic patients undergoing kidney biopsy. By contrast, rats bearing GH-secreting tumors displayed significant glomerular hypertrophy and interstitial edema but no tubular hypertrophy, resulting in a 1.6-fold increase in kidney weight in relation to body weight compared to controls [95]. However, GH levels are lower in acromegalic patients compared to animals that are not treated. Therefore, the discrepancy of the histological results obtained in acromegalic animals and humans may be, at least partly, due to significantly more pronounced $\mathrm{GH}$ excess in animals compared to humans.

Glomerular function Acromegalic patients show glomerular hyperfiltration characterized by an approx. $15 \%$ increase in GFR and RPF compared to healthy subjects, which is reversible in most but not all patients by surgical removal of pituitary adenomas $[62,72,96]$. Persistent glomerular hyperfiltration is thought to contribute to the development of albuminuria in acromegalic patients undergoing delayed surgery $[97,98]$. In the Baldelli study, microalbuminuria was reported in $55 \%$ of acromegalic patients and associated with hypertension, impaired glucose tolerance and diabetes [99].

Tubular function Acromegalic patients show an increase in total body water and sodium and may present with overt edema. These changes are related to the sodium-retaining properties of GH and IGF-1 via ENaC in the renal distal tubules (vide supra) and can be reversed if patients undergo effective treatment of the GH-producing tumor [100]. Total (56\% versus $50 \%$ of body weight) and extracellular body water $(20 \%$ versus $15 \%$ of body weight), as well as exchangeable sodium, were shown to be increased in acromegalic patients compared to healthy subjects, whereas no differences were noted in intracellular water content $[56,101]$. Plasma volume was also found to be increased in these patients [102-104]. The clinical consequences of these alterations are arterial hypertension, left ventricular hypertrophy and congestive heart failure, all contributing to the overall increased mortality in untreated patients [100]. Important to note, arterial hypertension is associated with an inferior outcome in these patients $[100,105]$. In addition, diabetic acromegalic patients present with more pronounced left ventricular hypertrophy compared to nondiabetic patients [106].

Acromegalic patients often present with mild hyperphosphatemia despite increased GFR, due to increased TmP/GFR, which can be used as a comprehensive measure of disease status and can be reversed with treatment [107]. The underlying mechanisms include, IGF-1-induced up-regulation of the Na-Pi 2a cotransporter in the renal proximal tubules, as well as enhanced intestinal phosphate absorption, due to GHinduced increased calcitriol synthesis (vide supra). Patients often show serum concentrations toward the upper normal range in association with hypercalciuria [108]. These findings are most likely related to GH-induced calcitriol synthesis (vide supra), with consecutively increased intestinal calcium 
absorption, as calcitriol levels tend to be elevated in these patients [108]. In addition, enhanced calcium absorption in the kidneys was demonstrated in acromegalic patients which is most likely related to calcitriol-induced stimulation of TRPV5 expression in the distal renal tubules (vide supra) [109]. The altered calcium metabolism was thought to contribute to the increased skeletal fragility noted in acromegalic patients [110].

Circulating levels of sKlotho are markedly increased in acromegalic patients and return to normal in parallel with GH and IGF-1 levels after tumor removal [111, 112]. Therefore, using sKlotho levels as a measure of disease status in these patients was suggested [112]. Since $\alpha$-Klotho is not expressed in pituitary adenoma, elevated sKlotho levels are most likely due to increased renal $\alpha$-Klotho and consecutively, enhanced cleavage of its extracellular domain as the main source of sKlotho (vide supra) $[112,113]$.

\section{GH/IGF-1 transgenic mice}

Transgenic mice overexpressing human, bovine or rat $G H$ genes exhibit excessive GH and IGF-1 concentrations resulting in a giant phenotype and organomegaly, including increased kidney weight even when related to increased body weight (Fig. 1) [114-119]. In addition, these animals develop glomerular hypertrophy, mesangial proliferation and matrix deposition at around 4 weeks. This is accompanied by podocyte injury, characterized by podocyte hypertrophy, foot process effacement and detachment of podocytes from the glomerular basement membrane. The consequences are albuminuria and progressive kidney failure, resulting in complete glomerulosclerosis and kidney failure at around 37 weeks of age. By contrast, transgenic mice overexpressing IGF-1 show less pronounced glomerular hypertrophy and do not develop glomerulosclerosis [120, 121]. In order to dissociate the contributions of GH and IGF1 -excess from the development of kidney damage, Blutke et al. compared the renal phenotype of IGF-1-deficient mice $\left(I^{-/-}\right)$, IGF-1-deficient GH-transgenic mice $\left(I^{-/-} / G\right)$, GHtransgenic mice $(G)$, and wild-type mice $[122,123]$. Both, $G$ mice and $I^{-/} / G$ mice developed the aforementioned pathological glomerular changes. However, this was much less pronounced in $I^{-/-} / G$ compared to $G$ mice. In addition, tubular hypertrophy was observed in $G$ mice but not in $I^{-/-} / G$ mice. The authors concluded that GH-excess is able to promote severe glomerular damage in mice in the absence of IGF-1, whereas tubular hypertrophy observed in GHtransgenic mice is most likely mediated by concomitant IGF-1 excess. It must be mentioned that GH serum levels in GH-transgenic mice are orders of magnitude above those noted during rhGH-treatment in patients with GHdeficiency or CKD. Even in acromegaly, the GH-secretion rates are higher than the amount of rhGH given for treatment of growth failure [124].

\section{GH deficiency}

In principle, the renal changes observed in patients with $\mathrm{GH}-$ deficiency mirror those observed in patients with GH-oversecretion. The availability of $\mathrm{rhGH}$ for treatment of $\mathrm{GH}$ deficient patients enabled detailed analysis of the renal effects of GH in these patients.

\section{Kidney morphology}

GHR $^{-/-}$mice present with reduced kidney size even after correction of reduced body weight. Also, kidneys in adult IGF-1 ${ }^{-/-}$mice are less than half the size compared to wildtype animals, and, IGF-1 $\mathrm{R}^{-/}$mice displayed severe intrauterine growth retardation and died immediately after birth, presenting hypoplastic organs including the kidneys [27, 125, 126].

Analogous to the experimental findings in rodents stated above, patients with GH-displaying mutations in the $G H$, $G H R$, and $I G F 1$ genes present with reduced kidney sizes [127-129]. Hypophysectomy in humans results in a reduction in kidney size by $20 \%$ after 5 months [130]. Treatment with rhGH in adult patients with childhood-onset GH-deficiency results in normalization of kidney size [131]. Equally, treatment with recombinant human IGF-1 (rhIGF-1) in children with severe IGF-1 deficiency, due to GHR-insensitivity, was shown to increase kidney length [132]. Unfortunately, no information is available on renal histopathological changes in GH or IGF-1-deficient patients.

\section{Glomerular function}

Humans with GH and IGF-1 deficiency display reduced GFR and RPF [133-135]. Similarly, hypophysectomy in humans results in a rapid decrease in GFR, even when patients receive hormone replacement for all pituitary deficiencies, except GH [130]. GH-replacement therapy restores GFR and RPF in some but not all studies, which is probably related to differences in duration of therapy and GH dose [134-136]. Treatment with rhIGF-1 in patients with GH-insensitivity also restores GFR [133].

\section{Tubular function}

GH-deficient children and adults display reduced sodium and total body water content and reduced extracellular and plasma volume compared to healthy subjects, while body fat mass is increased [137, 138]. All these changes can be normalized by rhGH-replacement therapy. Higher rhGH-doses may even result in acute fluid retention, leading to symptoms such as 
edema, weight gain, and carpal tunnel syndrome which usually disappears after dose-reduction or spontaneously [139]. Treatment with rhIGF-1 was shown to improve hydration status in children with GHR-insensitivity, further supporting the concept that the sodium and water-retaining properties of GH are at least partly mediated by IGF-1 (vide supra) [60].

Several randomized placebo-controlled trials on rhGHreplacement therapy in children and adults showed significant increases in serum calcium and urinary calcium concentrations in rhGH-treated patients. However, these effects were often transient, usually lasting 3-6 months, and no significant differences were noted at 9-12 months compared to controls [140-143]. Treatment with rhIGF-1 in children and adults with GHR-insensitivity resulted in increases in urinary calcium excretion, whereas serum calcium levels remained constant $[60,144]$. These effects are most likely due to IGF-1induced increased calcitriol synthesis, resulting in enhanced intestinal and renal calcium absorption (vide supra). Indeed, GH-replacement therapy, as well as treatment with rhIGF-1, increased serum calcitriol levels in GH-deficient patients [145, 146]. The latter was already observed within 3 days of treatment. Although theoretically this would have been expected (vide supra), no significant changes in intestinal calcium absorption were noted in GH-deficient patients receiving treatment with rhGH or rhIGF-1 [147].

As expected, GH-replacement therapy in children and adults improves TmP/GFR with consecutive increases in serum phosphate levels. In contrast to its effects on serum calcium, the antiphosphaturic effects of rhGH persist for at least 2 years [143, 148, 149]. By contrast, the antiphosphaturic effects of rhGH-treatment in children with inherited renal hypophosphatemia, i.e., X-linked hypophosphatemic rickets, were only transient, indicating the importance of other phosphaturic hormones, i.e., fibroblast growth factor 23 , in this particular disease [50].

\section{GH in kidney disease}

\section{Unilateral and subtotal nephrectomy}

Patients born with a solitary functioning kidney or undergoing unilateral nephrectomy show compensatory growth of the remaining kidney, with increased glomeruli and tubular sizes and increased single nephron GFR, resulting in normalization of total GFR. These adaptive mechanisms result in glomerular hyperfiltration and increased glomerular capillary pressure and are associated with kidney injury and hypertension in the long run [150]. There is evidence that alterations in the GH/IGF-1 axis contribute to this scenario, at least in the early stages. In adult rodents, unilateral nephrectomy results in an early but transient rise in the expression of IGF-1 mRNA in the remaining kidney and a transient rise in systemic GHconcentrations, whereas IGF-1R levels in the kidney are unaffected [151-153]. Therefore, locally synthesized, as well as increased circulating IGF-1, may contribute to the rapid compensatory kidney growth in mature rats after unilateral nephrectomy. By contrast, nephrectomy in immature rats was not associated with changes in circulating GH and IGF1 levels but increased renal IGF-1 synthesis, which was limited to the first 7 days only, although compensatory growth continues for several months in this model $[152,153]$. Therefore, there is no evidence that the GH/IGF-1 system is involved in compensatory kidney growth after this early period and other mechanisms including increased NO production and renal sympathetic nerve activity and/or activation of the RAAS may be the major factors maintaining compensatory kidney growth [150].

\section{Chronic kidney disease}

Chronic kidney disease results in profound alterations of the somatotropic hormone axis [154]. Fasting GH-concentrations were reported to be normal or even increased in CKD patients, caused by a prolonged plasma GH half-life, due to reduced GH clearance by the kidneys $[42,155]$. By contrast, endogenous GH secretion was shown to be normal or even slightly decreased in pubertal children with CKD. CKD results in impaired GHR and GH signaling characterized by an altered GH-induced hepatic, as well as growth plate cartilage IGF-1 synthesis, due to a reduced expression of the GHR and/or a postreceptor signaling defect [156-158]. The JAK2/STAT5 signaling pathway is activated after binding $\mathrm{GH}$ to its receptor, followed by transcriptional activation of IGF-1 synthesis and induction of SOCS proteins acting as a negative feedback loop (vide supra). CKD results in an altered equilibrium between activation of IGF-1 and SOCS, toward a markedly increased SOCS synthesis, which is most likely due to CKD-associated chronic inflammation resulting in a state of GH-insensitivity $[156,157]$. In addition, there is also evidence for IGF-1insensitivity in CKD [159]. IGF-1 and IGF-2 serum concentrations were found to be within the normal range in children with CKD stages $1-4$, while IGF-1 concentrations were slightly reduced, and those of IGF-2 slightly increased in patients with more advanced CKD [160]. Children with advanced CKD showed reduced somatomedin bioavailability, partly due to accumulation of IGFBPs (IGFBP-1, -2, -4, and -6), which are normally cleared by the kidneys. In addition, increased hepatic synthesis of IGFBP-1 and -2 was demonstrated in experimental uremia [161]. Finally, impaired cellular IGF signaling was demonstrated in experimental uremia [162].

In summary, the findings of impaired IGF-1 synthesis, together with modest elevation of GH-levels due to decreased renal clearance, and increased IGF plasma binding capacity, provides evidence of a multilevel, homeostatic failure in the GH-IGF-1 system in CKD, which has paved the way for 
studies proving the stimulatory growth effects of GH in short children with CKD [163]. A comprehensive review of the growth-promoting effects of rhGH and recommendations for its use in children with CKD was recently provided by Drube et al. [154]. In the following section, the effects of GH on kidney function in experimental uremia and in patients with CKD, before and after kidney transplantation (KTx), will be outlined.

Experimental studies GH-induced hyperfiltration may have adverse effects on kidney function in CKD. Miller et al. investigated the effects of recombinant bovine $\mathrm{GH}(\mathrm{bGH})$ and rhIGF- 1 on kidney function in normal and $5 / 6$ nephrectomized rats by inulin and p-aminohippurate clearances over 10-17 days. GFR in 5/6 nephrectomized rats decreased to $17 \%$ one day after $5 / 6$ nephrectomy, compared to controls, and slightly increased during the next 3 days [164]. However, in contrast to healthy rats showing sustained increases in GFR and RPF during treatment with bGH and rhIGF-1, no significant effects of these measures on GFR, RPF or filtration fraction were noted in 5/6 nephrectomized rats. Equally, a 7-day treatment with exogenous rat or rhGH, or rhIGF-1, failed to increase GFR in 5/6 nephrectomized rats in subsequent studies [165]. Since uremic animals also failed to show increases in GFR and RPF after amino acid infusion, known to enhance kidney function in healthy animals, the authors concluded that the vasodilatory eicosanoids are already maximally stimulated under baseline conditions in uremic animals and, consequently, renal reserve capacity is diminished in these animals.

Allen et al. demonstrated that prolonged treatment with rhGH for periods of up to 25 weeks did not adversely affect GFR compared to control animals [166]. Interestingly, kidney-to body-weight-ratio was normalized in rhGH-treated animals, due to much more pronounced glomerular hypertrophy in rhGH-treated rats when compared to uremic controls, as demonstrated by renal histological examination. In addition, both uremic controls and rhGH-treated uremic animals showed a significantly increased mean sclerotic index, compared to healthy rats, which was even more pronounced in rhGH-treated animals, suggesting that the beneficial effects of prolonged rhGH-treatment on kidney growth results in progressive glomerulosclerosis in rodents. Similar results were reported by Kawaguchi et al., investigating the renal effects of an 8-week treatment of various rhGH-doses $(0.4,2.0$, and $10 \mathrm{IU} /$ day) in subtotally nephrectomized rats [167]. Whereas low rhGH-doses did not result in significant changes in GFR or glomerular sclerosis index compared to controls, medium and high-dose rhGH-treatment resulted in a significantly lower creatinine clearance and glomerularsclerosis index. The translation of these results to the setting of chronic rhGHtreatment in children with CKD is hampered by the fact that the rhGH-dosages in these studies (approx. $3 \mathrm{mg} / \mathrm{kg}$ body weight (BW) per day) were 60-fold higher compared to those used for treatment of CKD-associated growth failure $(0.05$ $\mathrm{mg} / \mathrm{kg}$ BW per day). Nevertheless, this data indicates that special attention should be paid to the use of rhGH in children with CKD, especially when given over prolonged periods [154].

\section{Clinical studies}

rhGH treatment Three-day administration of rhGH at dosages comparable to those used for uremic growth failure did not increase GFR in adult CKD patients with a median baseline GFR of $21 \mathrm{ml} / \mathrm{min} / 1.73 \mathrm{~m}^{2}$, despite significant anabolic effects with respect to serum cholesterol levels and urea excretion rates [33]., Tönshoff et al. also showed no significant increases in GFR in uncontrolled studies on rhGH-treatment in children with CKD stages 3-4 (median GFR, $19 \mathrm{ml} / \mathrm{min} /$ $1.73 \mathrm{~m}^{2}$ ) and after KTx (median GFR, $47 \mathrm{ml} / \mathrm{min} / 1.73 \mathrm{~m}^{2}$ ) after a 6-week treatment period [168]. Maxwell et al. investigated GFR and RPF in 18 children with CKD (median GFR, $19 \mathrm{ml} / \mathrm{min} / 1.73 \mathrm{~m}^{2}$ ) during their first year of rhGH-treatment [169]. GFR at $3 \mathrm{~h}$ after first rhGH-injection, at day 8 and after 1 year remained unchanged, compared to baseline values. By contrast, a significant transient increase in RPF was noted on day $8\left(96(33-276) \mathrm{ml} / \mathrm{min} / 1.73 \mathrm{~m}^{2}\right.$ versus $77(34-271) \mathrm{ml} /$ $\min / 1.73 \mathrm{~m}^{2}$ ). This data suggests that $\mathrm{GH}$ does not augment kidney function in humans with CKD stages 3-4 and may be due to GH-insensitivity associated with CKD and/or generally limited renal reserve capacity in these patients (vide supra). However, there is limited data suggesting that GH may increase GFR in patients with mild CKD. GFR was significantly increased after 1 week and 6 months of rhGH-therapy in a cohort of 16 pediatric KTx patients with CKD stages 2-3, but returned to baseline values thereafter, whereas no changes in RPF were noted (GFR: baseline $52 \mathrm{ml} / \mathrm{min} / 1.73 \mathrm{~m}^{2}, 1$ week $57 \mathrm{ml} / \mathrm{min} / 1.73 \mathrm{~m}^{2}, 6$ months $63 \mathrm{ml} / \mathrm{min} / 1.73 \mathrm{~m}^{2}$ ) [170].

Nine randomized controlled trials (RCTs) revealed no evidence of adverse effects of rhGH on estimated GFR (eGFR) over treatment periods of up to 2 years in children with CKD stages 2-4 [171]. Patients suffering from nephropathic cystinosis are especially prone to progressive CKD, despite treatment with cysteine-lowering agents. Wühl et al. investigated the evolution of eGFR values in children with nephropathic cystinosis started on rhGH-treatment and enrolled in a European multicenter trial, compared to that of a historical control group with comparable ages and eGFR [172]. The decline in mean eGFR was comparable in rhGH-treated patients compared to controls, irrespective of concomitant cysteamine treatment. Mehls et al. assessed the effects of rhGH on eGFR in children with CKD stages $2-4$, using data from two large prospective clinical studies involving children with (KIGS registry) and without rhGH-therapy (ESCAPE trial) [173]. In both studies, eGFR was assessed cross-sectionally 
in yearly intervals for up to 10 years and longitudinally for 5 years. Overall, patients showed only a mild progression in CKD during the observation period. The mean decline in eGFR at 5 years compared to baseline did not significantly differ between groups (KIGS, $-5.8 \mathrm{ml} / \mathrm{min} / 1.73 \mathrm{~m}^{2}$; ESCAPE, $-8.6 \mathrm{ml} / \mathrm{min} / 1.73 \mathrm{~m}^{2}, p=0.17$ ) (Fig. 2). In both patient cohorts, the change in eGFR after 5 years was significantly associated with age and height at baseline. It must be mentioned that rhGH-treatment is known to improve muscle mass in CKD which may have resulted in an increase in serum creatinine and, consequently, a decrease in eGFR in the KIGS cohort. However, this further supports the findings that rhGHtherapy does not lead to accelerated progression of CKD in children. Recent experimental studies suggest that the safety of prolonged rhGH-treatment in CKD may be, at least partly, due to GH-insensitivity in the kidney in these patients. Landau et al. noted reduced expression of the GHR in the kidneys of 5/ 6 nephrectomized animals, which was associated with elevated pro-inflammatory cytokines, suggesting that GHinsensitivity in uremia is a general phenomenon and not restricted to the liver and growth plates (vide supra) [174].

Concern has been raised that rhGH may stimulate the immune system in KTx patients and thereby promote acute rejection episodes with the consequence of poor graft outcome in children. However, a recent meta-analysis of 5 RCTs on rhGH-treatment after KTx including 401 children revealed no increased risk for acute rejection episodes (risk ratio 1.56; 95\% CI $0.97-2.53, p=0.07$ ) or increased decline in eGFR (delta eGFR at 1 year, $3.27 \mathrm{ml} / \mathrm{min} / 1.73 \mathrm{~m}^{2} ; 95 \% \mathrm{CI}-3.54$ $10.09, p=0.35)[175]$.

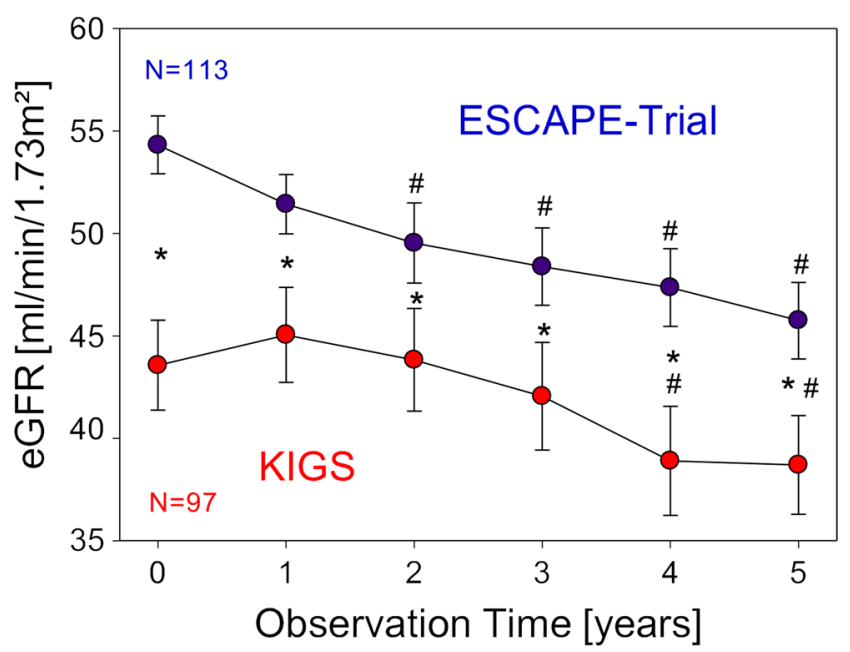

Fig. 2 Changes in estimated glomerular filtration rate (eGFR) during the 5 -year longitudinal follow-up. eGFR decline within 5 years was not significantly different between recombinant human growth hormone (rhGH)-treated (KIGS register) and non-rhGH-treated (ESCAPE trial) patients. Data is given as the mean \pm standard error of the mean (SEM). *Significant differences between groups, " significant difference from baseline. Figure reproduced with permission from Mehls et al. [173].
Taken together, there is no evidence that rhGH-treatment accelerates the decline of kidney function in children with $\mathrm{CKD}$ or promotes acute rejection episodes after KTx. when using the recommended rhGH standard dose $(0.045-0.05$ $\mathrm{mg} / \mathrm{kg}$ per day, s.c.). Nevertheless, a European guideline recommends that eGFR should be monitored in at least 3-month intervals in children with CKD started on rhGH treatment, and that treatment should be discontinued in patients presenting with an unexplained decline in eGFR [154].

rhIGF-1 treatment O'Shea et al. investigated the renal effects of a 3-day rhIGF-1 treatment $(100 \mu \mathrm{g} / \mathrm{kg}$ twice daily) in 4 adult patients with advanced CKD (GFR 21-55 ml/min/1.73 $\mathrm{m}^{2}$ ) showing significant increases of both GFR and RPF in all patients, which was associated with a small increase in kidney size [176]. The same group later investigated whether a longer rhIGF-1 treatment (20 days) in patients with more advanced CKD (GFR $\left.\leq 21 \mathrm{ml} / \mathrm{min} / 1.73 \mathrm{~m}^{2}\right)$ would have similar results [177]. Although, there was an initial rise in GFR (32\%), RPF (28\%) and the percentage of tubular reabsorption of filtered phosphate at day 4 , all these parameters returned to baseline levels after 13 or 20 days of rhIGF-1 treatment, but the patients developed severe side effects, including jaw pain, nasal congestion and Bell's palsy, requiring discontinuation of rhIGF-1 treatment in 4 of 9 patients. In a subsequent RCT of the same group, a lower IGF-1 dosage ( $50 \mu \mathrm{g} / \mathrm{kg}$ twice daily) and intermittent treatment protocol, with cycles of 4-day treatment interrupted by 3 days off treatment, in patients with stage 5 CKD (GFR 6-15 ml/min $/ 1.73 \mathrm{~m}^{2}$ ) was used [178]. RhIGF-1 resulted in significant, sustained increases in GFR (42-81\%) over a treatment period of 45 days. One patient showed mild edema and two patients displayed irritation at the injection site. Several patients in whom treatment was continued remained off dialysis for up to 18 months after initiation of rhIGF-1 treatment. Interestingly, GFR remained increased even 14 days after cessation of rhIGF-1 therapy compared to placebo-treated controls, suggesting that rhIGF-1 resulted in renal hypertrophy, since the hemodynamic effects should have worn off within 14 days of cessation. However, adequately powered RCTs are needed to prove the long-term efficacy and safety of rhIGF-1-treatment to enhance GFR in patients with advanced CKD.

\section{Acute kidney injury}

Experimental studies Ischemic acute kidney injury (AKI) in rodents and humans results in preferential damage of the distal segment of the proximal tubule $\left(\mathrm{S}_{3}\right.$-segment $)$ and the thick ascending limb of the loop of Henle, indicated by loss of brush borders, cell necrosis and apoptosis, since this part of the nephron heavily depends on medullary blood flow in order to preserve oxygen supply [179]. Observations in rodents showed that the proximal tubule has IGF-1Rs and is 
responsive to IGF-1, and that renal IGF synthesis, including the collecting duct, is transiently increased in animal models of postischemic AKI, thereby providing the rationale for the use of rhGH or rhIGF-1 in AKI in order to improve kidney regeneration [3].

Miller et al. performed the first study showing evidence that treatment with rhIGF-1 improves renal recovery after postischemic injury in rodents [180]. Rats treated with IGF-1, either $24 \mathrm{~h}$ before ischemic AKI, immediately after or $24 \mathrm{~h}$ after, showed accelerated recovery of GFR and histopathological changes in damaged proximal tubular epithelia, as well as improved mortality. These results were later confirmed by several other groups using various animal models of ischemic or toxic AKI [181-183]. The beneficial effects of IGF-1 treatment in AKI may be due to the following: (1) its stimulatory effect on GFR via increased renal blood flow (vide supra), which prevents the obstruction of tubules by cellular debris and thereby limiting the extent of kidney injury; (2) its positive anabolic effects, including reduced protein breakdown; (3) its stimulatory effect on DNA synthesis in regenerating renal tubular cells; and (4) a reduced apoptosis rate after reperfusion [2].

Due to the positive effects of IGF-1 on kidney regeneration after AKI, Matejka and Bengtsson investigated the effects of high-dose rhGH-therapy in an animal model of postischemic AKI [184]. Rats underwent renal ischemia for $45 \mathrm{~min}$. After reperfusion, the animals were started on rhGH-treatment (2 $\mathrm{mg}$ /day). Although rhGH-treatment partly restored reduced expression of GHR and IGF-1 in the kidneys and resulted in profound metabolic effects, including improved weight gain and lower urea serum levels, there was no difference with respect to renal recovery and mortality compared to placebotreated controls. These negative results suggest severe GHinsensitivity in AKI, which cannot be overcome by exogenous treatment with rhGH, which contrasts with the results of rhGH-treatment in animals and humans with CKD.

Clinical studies The effects of treatment with rhGH on renal recovery in patients with AKI was investigated in two RCTs. Franklin et al. showed that rhGH given after surgical interventions resulting in transient interruption of renal blood flow prevented the decrease in GFR noted in placebo-treated controls [185]. However, the incidence of AKI in this study was too low to draw meaningful conclusions on whether IGF-1 ameliorates the course of AKI. A second large placebocontrolled trial in patients with established AKI was terminated early, since an interim analysis showed no beneficial effects of rhIGF-1 treatment [3]. The negative results of the latter study may, at least partly, be due to the large heterogeneity of causes of AKI (trauma, hypertension, surgery, drugs or sepsis) and/or the delayed initiation of rhIGF-1 treatment, i.e., after established AKI.

\section{Diabetic nephropathy}

Patients with poorly controlled type 1 diabetes mellitus (T1DM) present with markedly enhanced pituitary GHsecretion rates, probably related to decreased hypothalamic somatostatin tone and exaggerated GH-responses to physiological and pharmacological stimuli $[186,187]$. The primary underlying pathomechanism is most likely a decreased hepatic GHR expression related to insulin deficiency, resulting in GHresistance and impaired hepatic IGF-1 synthesis, which stimulates pituitary GH-secretion by a feedback mechanism [188, 189]. In addition, hypoinsulinemia in T1DM stimulates hepatic synthesis of IGFBPs, resulting in increased IGF-binding capacity and, consequently, reduced IGF-1 bioactivity which further stimulates GH-secretion [190-192]. Since GHR expression in the kidney is unaltered in T1DM, elevated circulating GH-concentrations can impact on the kidney. Indeed, patients with T1DM present with increased GFR (25-50\%), glomerular hypertrophy and increased kidney size during the early course of the disease, which may promote the development of diabetic nephropathy [193, 194]. The latter is characterized by glomerular hyperfiltration, glomerular/tubular hypertrophy, and thickening of the glomerular basement membrane and mesangial matrix expansion/proliferation, resulting in increased glomerular permeability with consecutive albuminuria and progressive CKD [195]. In addition, loss of podocytes, either due to apoptosis and/or podocyte detachment from the glomerular basement membrane, was shown to be an early event in the development of diabetic nephropathy in humans and various animal models of diabetic nephropathy [196-198].

The first evidence that excessive GH-levels are involved in the pathogenesis of diabetic microangiopathy came from observations in diabetic patients undergoing pituitary ablation, which resulted in improvement of diabetic retinopathy in some but not all patients [199]. Urinary GH and IGF-1 levels are associated with the presence of microalbuminuria in patients with T1DM [200, 201]. In addition, urinary IGF-1 concentrations are associated with kidney size and microalbuminuria in these patients [201].

As outlined above, GHR and IGF-1R are highly abundant in glomerular cells, including podocytes and mesangial cells, and can be activated by GH and IGF-1, respectively. Excessive levels of GH were shown to induce glomerular hypertrophy and glomerulosclerosis, which may be directly caused by GH or mediated by IGF-1 (vide supra). Alongside their humoral actions, both GH and IGF-1 can target the kidney in an autocrine and/or paracrine manner. Although GHR abundance in the liver in diabetic rats is reduced, GHR expression in kidneys was shown to be evenly increased, suggesting tissue-specific expression of GHR [202]. Reduced circulating IGF-1 and growth failure were also reported in T1DM patients, while IGF-1 concentrations in renal tissue were shown 
to be increased, suggesting increased local synthesis and/or IGF-1 sequestration from the circulation [203, 204]. In addition, increased IGFBP levels were reported in kidneys from diabetic rats, which may also contribute to increased renal IGF-1 levels [205]. Finally, GH signal transduction and IGF-1R expression were shown to be increased in streptozotocin-induced diabetic rats [206].

Further evidence comes from interventional studies in animal models of diabetic nephropathy targeting the GH/IGF system. Treatment with GH antagonists or somatostatin analogs, as well as genetic disruption or pharmacological blockade of the GHR, resulted in amelioration of experimental diabetic nephropathy, including normalization of diabetesassociated renal hypertrophy and glomerular enlargement, as well as albuminuria [203, 207-210]. These studies support the concept that a functional GHR is essential for the development of diabetic nephropathy in murine models of T1DM. Two studies in patients with T1DM further support this concept. Infusion with a somatostatin analog, SMS 201-995, acutely reduced GFR and RPF in uncomplicated patients with T1DM [211]. In addition, a significant reduction in kidney volume and hyperfiltration was noted after a three-month treatment in T1DM patients treated with octreotide, a somatostatin analog, compared to placebo-treated patients [212].

GH-induced increased podocyte permeability to proteins was originally thought to be related to increased expression of ZEB2, resulting in downregulation of E- and P-cadherins (vide supra). The same group recently revealed a new mechanism of GH-induced podocyte injury. They could demonstrate that $\mathrm{GH}$ increases expression of transforming growth factor-beta-induced protein (TGFBIp) in cultured podocytes with consecutively enhanced TGFBIp secretion in cell supernatant [195]. TGFBIp expression was also increased in renal tissue from patients with diabetic nephropathy. Both treatment with GH and TGFBIp increased podocyte migration, as well as podocyte permeability to albumin across podocyte monolayers. Finally, renal histological studies in animals treated with GH showed glomerular mesangial matrix expansion and increased apoptosis of podocytes. Taken together, these studies suggest that GH induces TGFBIp in podocytes, which may contribute to podocyte depletion in diabetes mellitus. The authors speculated that targeting TGFBIp may be an effective measure in preventing podocyte loss and, thereby, ameliorate progression of kidney disease in patients with T1DM. Nishad et al. revealed an additional potential mechanism of GHinduced podocyte injury [213]. By use of cultured immortalized podocytes and mouse models, they could demonstrate that GH excess activates Notch1 signaling in podocytes resulting in podocyte loss. Pharmacological inhibition of Notch1 prevented GH-induced glomerular fibrosis, glomerular basement membrane thickening and albuminuria in vivo. Upregulated Notch signaling was also noted in kidney biopsy sections from patients with diabetic nephropathy. These studies suggest that inhibition of GH-induced Notch1 signaling may be a promising measure in preventing diabetic nephropathy.

Important to note, GH was demonstrated to have nephroprotective effects as well [214]. GH treatment protected cisplatin-induced nephropathy in rats by reversing upregulated oxidative stress and inflammatory biomarkers (high mobility group box protein-1 and nuclear factor kappa B). Therefore, the results of the abovementioned studies should not be translated to other clinical settings.

Taken together, GH excess associated with poorly controlled T1DM induces podocyte injury, characterized by podocyte hypertrophy, apoptosis, dedifferentiation of podocytes (epithelial-mesenchymal transition) and/or crosslinking of the basement membrane resulting in increased podocyte permeability to albumin and detachment of podocytes from the glomerular basement membrane (Fig. 1). Therefore, GH excess may be an important promoter of diabetic nephropathy in poorly controlled T1DM patients.

\section{Nephrotic syndrome}

Clinical and experimental data have demonstrated profound disturbances of IGF-1/-2 and its binding proteins in the circulation and urine, which were originally thought to be due to increased glomerular permeability and urinary losses of these proteins $[215,216]$. In pediatric patients with nephrotic syndrome and normal eGFR, mean standardized values of IGF-1 were found to be significantly decreased $(-0.53 \mathrm{SD})$, whereas IGF-2 levels were increased (0.68 SD) [215]. Urinary excretion rates of IGF-1 and 2 were 5-fold increased, compared to healthy controls. Although, IGFBP-1 and 2 urinary excretion rates were 12 -fold and 2-fold increased, the respective serum concentrations of these peptides were markedly increased (IGFBP-1, 2.05 SD; IGFBP-2, 5.97 SD). Fast liquid chromatography (FPLC) analysis of nephrotic serum revealed a decreased $150 \mathrm{kDA}$ IGFBP ternary complex due to reduced intact IGFBP-3, whereas IGFBP-3 low molecular weight fragments were markedly increased, suggesting increased proteolytic degradation of IGFBP-3. In both patients and controls only IGBP-3 fragments but no intact IGFBP-3 could be detected, which was associated with the degree of proteinuria. By contrast, serum levels of the ALS and GHBP were found to be normal in nephrotic patients. Taken together, in children with nephrotic syndrome IGF-1 levels are decreased and highaffinity IGFBPs (mainly IGFBP-1/-2) are markedly increased, resulting in an excess of unsaturated IGFBPs which may inhibit IGF action on target tissues by enhanced IGF-binding and/or competition with the IGF-1R. The authors hypothesized that these alterations may contribute to catabolism and impaired growth in children suffering from long-standing nephrotic syndrome. 
Studies in nephrotic rats performed by Hirschberg and coworkers revealed deep insights into the pathophysiology of the IGF/IGBP system in nephrotic syndrome. By use of micropuncture studies in rats with adriamycin-induced nephrotic syndrome, they could demonstrate that IGF-1 serum concentrations are markedly reduced and IGF-1 is highly ultrafiltrated together with IGFBP-2 appearing in proximal tubular fluid [217]. In line with the findings in humans, IGFBP-2 serum concentrations were markedly increased in nephrotic animals despite excessive urinary losses due to increased hepatic synthesis, whereas hepatic synthesis of IGFBP-3 was unchanged compared to controls. Western immune analysis suggested in vivo proteolysis of intact IGBF-3, resulting in reduced binding to IGFBP-3 and increased lowmolecular weight IGFBP-3 fragments.

In their subsequent in vitro studies using cultured proximal tubular cells, they could demonstrate that proximal tubular fluid from nephrotic rats activates IGF-1R, suggesting that filtered IGF-1 is bioactive [218]. In addition, the tubular ultrafiltrate from nephrotic rats stimulated collagen types I and IV synthesis in cultured tubular cells, suggesting that the excessive losses of IGF-1 in the nephrotic state may promote tubular-interstitial fibrosis and thereby, progressive kidney disease in patients with persistent nephrotic syndrome [219].

\section{GH in patients with healthy kidneys}

Concern has been raised that children treated for short stature not due to kidney diseases, receiving long-term rhGH-treatment may develop CKD in the long run. A recent, large, prospective study evaluated eGFR, blood pressure and microalbuminuria at 6 months, 2 years and 5 years after cessation of rhGH-treatment in adults born small for gestational age (SGA) [220]. A significant decrease in eGFR was noted at 6 months only. Mean blood pressure values and albuminuria did not differ in patients with prior rhGH-treatment compared to healthy controls born SGA during the follow-up period. This confirms previous clinical studies and registry analyses on the renal safety profile of rhGH-treatment in children with short stature of nonrenal origin [221-224].

\section{Summary and conclusion}

The GH/IGF-1 system is an important regulator of kidney function, including glomerular hemodynamics, renal gluconeogenesis, and tubular handling of phosphate, sodium, water, and calcium. The latter is mediated by GH/IGF-1-induced renal synthesis of $1,25(\mathrm{OH})_{2}$ vitamin $\mathrm{D}_{3}$. Treatment with rhGH increases GFR and RPF in healthy subjects via IGF-1induced synthesis of the endogenous vasodilator NO. GHexcess in acromegalic patients and GH-transgenic animals can result in glomerular hyperfiltration, renal hypertrophy, and glomerulosclerosis. Likewise, elevated GH in patients with poorly controlled T1DM was also shown to promote diabetic nephropathy in these patients. Therefore, concern was raised that long-term treatment with rhGH in short children with CKD may accelerate CKD progression. However, clinical and experimental studies demonstrate the long-term safety of this treatment in subjects with impaired and normal kidney function. This discrepancy is probably due to the CKD-associated GH insensitivity of the kidneys, preventing GH actions on the glomerular cells and/or the considerably lower GH exposure in rhGH-treated patients, compared to GH excess in acromegalic patients and GH transgenic animals. Finally, GH was shown to increase the renal synthesis of the antiaging hormone Klotho in healthy subjects and patients with $\mathrm{CKD}$, indicating that $\mathrm{GH}$ treatment may have beneficial effects on the cardiovascular system. However, this has to be proven in adequately designed clinical studies.

Funding Open Access funding enabled and organized by Projekt DEAL.

Open Access This article is licensed under a Creative Commons Attribution 4.0 International License, which permits use, sharing, adaptation, distribution and reproduction in any medium or format, as long as you give appropriate credit to the original author(s) and the source, provide a link to the Creative Commons licence, and indicate if changes were made. The images or other third party material in this article are included in the article's Creative Commons licence, unless indicated otherwise in a credit line to the material. If material is not included in the article's Creative Commons licence and your intended use is not permitted by statutory regulation or exceeds the permitted use, you will need to obtain permission directly from the copyright holder. To view a copy of this licence, visit http://creativecommons.org/licenses/by/4.0/.

\section{References}

1. Kamenický P, Mazziotti G, Lombès M, Giustina A, Chanson P (2014) Growth hormone, insulin-like growth factor-1, and the kidney: pathophysiological and clinical implications. Endocr Rev 35:234-281

2. Feld S, Hirschberg R (1996) Growth hormone, the insulin-like growth factor system, and the kidney. Endocr Rev 17:423-480

3. Hammerman MR (1999) The growth hormone-insulin-like growth factor axis in kidney re-revisited. Nephrol Dial Transplant 14:1853-1860

4. Ogle GD, Rosenberg AR, Kainer G (1992) Renal effects of growth hormone. I. Renal function and kidney growth. Pediatr Nephrol 6:394-398

5. Ogle GD, Rosenberg AR, Kainer G (1992) Renal effects of growth hormone. II. Electrolyte homeostasis and body composition. Pediatr Nephrol 6:483-489

6. Lanning NJ, Carter-Su C (2006) Recent advances in growth hormone signaling. Rev Endocr Metab Disord 7:225-235

7. Bach LA (2018) IGF-binding proteins. J Mol Endocrinol 61:T11$\mathrm{T} 28$

8. Dehkhoda F, Lee CMM, Medina J, Brooks AJ (2018) The growth hormone receptor: mechanism of receptor activation, cell signaling, and physiological aspects. Front Endocrinol (Lausanne) 9:35 
9. Mathews LS, Enberg B, Norstedt G (1989) Regulation of rat growth hormone receptor gene expression. J Biol Chem 264: 9905-9910

10. Chin E, Zhou J, Bondy CA (1992) Renal growth hormone receptor gene expression: Relationship to renal insulin-like growth factor system. Endocrinology 131:3061-3066

11. Kamenicky P, Viengchareun S, Blanchard A, Meduri G, Zizzari P, Imbert-Teboul M, Doucet A, Chanson P, Lombès M (2008) Epithelial sodium channel is a key mediator of growth hormoneinduced sodium retention in acromegaly. Endocrinology 149: 3294-3305

12. Reddy GR, Pushpanathan MJ, Ransom RF, Holzman LB, Brosius FC 3rd, Diakonova M, Mathieson P, Saleem MA, List EO, Kopchick JJ, Frank SJ, Menon RK (2007) Identification of the glomerular podocyte as a target for growth hormone action. Endocrinology 148:2045-2055

13. Meinhardt U, Eblé A, Besson A, Strasburger CJ, Sraer JD, Mullis PE (2003) Regulation of growth-hormone-receptor gene expression by growth hormone and pegvisomant in human mesangial cells. Kidney Int 64:421-430

14. Doi SQ, Jacot TA, Sellitti DF, Hirszel P, Hirata MH, Striker GE, Striker LJ (2000) Growth hormone increases inducible nitric oxide synthase expression in mesangial cells. J Am Soc Nephrol 11: $1419-1425$

15. D'Ercole AJ, Stiles AD, Underwood LE (1984) Tissue concentrations of somatomedin $\mathrm{C}$ : further evidence for multiple sites of synthesis and paracrine or autocrine mechanisms of action. Proc Natl Acad Sci U S A 81:935-939

16. Roberts CT Jr, Lasky SR, Lowe WL Jr, Seaman WT, LeRoith D (1987) Molecular cloning of rat insulin-like growth factor I complementary deoxyribonucleic acids: differential messenger ribonucleic acid processing and regulation by growth hormone in extrahepatic tissues. Mol Endocrinol 1:243-248

17. Rogers SA, Miller SB, Hammerman MR (1990) Growth hormone stimulates IGF I gene expression in isolated rat renal collecting duct. Am J Phys 259:474

18. Lindenbergh-Kortleve DJ, Rosato RR, van Neck JW, Nauta J, van Kleffens M, Groffen C, Zwarthoff EC, Drop SL (1997) Gene expression of the insulin-like growth factor system during mouse kidney development. Mol Cell Endocrinol 132:81-91

19. Chin E, Zhou J, Bondy C (1992) Anatomical relationships in the patterns of insulin-like growth factor (IGF)-I, IGF binding protein1 , and IGF-I receptor gene expression in the rat kidney. Endocrinology 130:3237-3245

20. Cingel-Ristić V, Flyvbjerg A, Drop SL (2004) The physiological and pathophysiological roles of the GH/IGF-axis in the kidney: lessons from experimental rodent models. Growth Hormon IGF Res 14:418-430

21. Bondy CA, Werner H, Roberts CT Jr, LeRoith D (1990) Cellular pattern of insulin-like growth factor-I (IGF-I) and type I IGF receptor gene expression in early organogenesis: comparison with IGF-II gene expression. Mol Endocrinol 4:1386-1398

22. Rabkin R, Brody M, Lu LH, Chan C, Shaheen AM, Gillett N (1995) Expression of the genes encoding the rat renal insulinlike growth factor-I system. J Am Soc Nephrol 6:1511-1518

23. Chin E, Bondy C (1992) Insulin-like growth factor system gene expression in the human kidney. J Clin Endocrinol Metab 75:962968

24. Chin E, Michels K, Bondy CA (1994) Partition of insulin-like growth factor (IGF)-binding sites between the IGF-I and IGF-II receptors and IGF-binding proteins in the human kidney. J Clin Endocrinol Metab 78:156-164

25. Staruschenko A, Pochynyuk O, Vandewalle A, Bugaj V, Stockand JD (2007) Acute regulation of the epithelial na+ channel by phosphatidylinositide $3-\mathrm{OH}$ kinase signaling in native collecting duct principal cells. J Am Soc Nephrol 18:1652-1661
26. Gonzalez-Rodriguez E, Gaeggeler HP, Rossier BC (2007) IGF-1 vs insulin: respective roles in modulating sodium transport via the PI-3 kinase/Sgk1 pathway in a cortical collecting duct cell line. Kidney Int 71:116-125

27. List EO, Sackmann-Sala L, Berryman DE, Funk K, Kelder B, Gosney ES, Okada S, Ding J, Cruz-Topete D, Kopchick JJ (2011) Endocrine parameters and phenotypes of the growth hormone receptor gene disrupted (GHR-/-) mouse. Endocr Rev 32: 356-386

28. Nordstrom SM, Tran JL, Sos BC, Wagner KU, Weiss EJ (2011) Liver-derived IGF-I contributes to GH-dependent increases in lean mass and bone mineral density in mice with comparable levels of circulating GH. Mol Endocrinol 25:1223-1230

29. Corvilain J, Abramow M, Bergans A (1962) Some effects of human growth hormone on renal hemodynamics and on tubular phosphate transport in man. J Clin Invest 41:1230-1235

30. Hirschberg R, Rabb H, Bergamo R, Kopple JD (1989) The delayed effect of growth hormone on renal function in humans. Kidney Int 35:865-870

31. Hirschberg RR, Kopple JD (1988) Increase in renal plasma flow and glomerular filtration rate during growth hormone treatment may be mediated by insulin-like growth factor I. Am J Nephrol 8:249-254

32. Haffner D, Ritz E, Mehls O, Rosman J, Blum W, Heinrich U, Hubinger A (1990) Growth hormone induced rise in glomerular filtration rate is not obliterated by angiotensin-converting enzyme inhibitors. Nephron 55:63-68

33. Haffner D, Zacharewicz S, Mehls O, Heinrich U, Ritz E (1989) The acute effect of growth hormone on GFR is obliterated in chronic renal failure. Clin Nephrol 32:266-269

34. Christiansen JS, Gammelgaard J, Orskov H, Andersen AR, Telmer S, Parving HH (1981) Kidney function and size in normal subjects before and during growth hormone administration for one week. Eur J Clin Investig 11:487-490

35. Parving HH, Noer I, Mogensen CE, Svendsen PA (1978) Kidney function in normal man during short-term growth hormone infusion. Acta Endocrinol 89:796-800

36. Baumann U, Eisenhauer T, Hartmann H (1992) Increase of glomerular filtration rate and renal plasma flow by insulin-like growth factor-I during euglycaemic clamping in anaesthetized rats. Eur J Clin Investig 22:204-209

37. Guler HP, Eckardt KU, Zapf J, Bauer C, Froesch ER (1989) Insulin-like growth factor I increase glomerular filtration rate and renal plasma flow in man. Acta Endocrinol 121:101-106

38. Hirschberg R, Kopple JD (1989) Evidence that insulin-like growth factor I increases renal plasma flow and glomerular filtration rate in fasted rats. J Clin Invest 83:326-330

39. Hirschberg R, Kopple JD (1992) The growth hormone-insulinlike growth factor I axis and renal glomerular function. J Am Soc Nephrol 2:1417-1422

40. Hirschberg R, Kopple JD, Blantz RC, Tucker BJ (1991) Effects of recombinant human insulin-like growth factor I on glomerular dynamics in the rat. J Clin Invest 87:1200-1206

41. Tönshoff B, Kaskel FJ, Moore LC (1998) Effects of insulin-like growth factor I on the renal juxtamedullary microvasculature. Am J Phys 274:F120-F128

42. Tönshoff B, Nowack R, Kurilenko S, Blum WF, Seyberth HW, Mehls O, Ritz E (1993) Growth hormone-induced glomerular hyperfiltration is dependent on vasodilating prostanoids. Am J Kidney Dis 21:145-151

43. Tsukahara H, Gordienko DV, Tonshoff B, Gelato MC, Goligorsky MS (1994) Direct demonstration of insulin-like growth factor-I-induced nitric oxide production by endothelial cells. Kidney Int 45:598-604

44. Nissel R, Fischer DC, Puhlmann A, Holdt-Lehmann B, Mitzner A, Petzsch M, Korber T, Tiess M, Schmidt R, Haffner D (2009) 
Short-term growth hormone treatment and microcirculation: effects in patients with chronic kidney disease. Microvasc Res 78: 246-252

45. Kumar PA, Kotlyarevska K, Dejkhmaron P, Reddy GR, Lu C, Bhojani MS, Menon RK (2010) Growth hormone (GH)-dependent expression of a natural antisense transcript induces zinc finger E-box-binding homeobox 2 (ZEB2) in the glomerular podocyte: a novel action of gh with implications for the pathogenesis of diabetic nephropathy. J Biol Chem 285:31148-31156

46. Li CX, Xia M, Han WQ, Li XX, Zhang C, Boini KM, Liu XC, Li PL (2011) Reversal by growth hormone of homocysteine-induced epithelial-to-mesenchymal transition through membrane raftredox signaling in podocytes. Cell Physiol Biochem 27:691-702

47. Vasylyeva TL, Chen X, Ferry RJ Jr (2005) Insulin-like growth factor binding protein-3 mediates cytokine-induced mesangial cell apoptosis. Growth Hormon IGF Res 15:207-214

48. Levi M, Gratton E, Forster IC, Hernando N, Wagner CA, Biber J, Sorribas V, Murer H (2019) Mechanisms of phosphate transport. Nat Rev Nephrol 15:482-500

49. Corvilain J, Abramow M (1964) Effect of growth hormone on tubular transport of phosphate in normal and parathyroidectomized dogs. J Clin Invest 43:1608-1612

50. Zivicnjak M, Schnabel D, Staude H, Even G, Marx M, Beetz R, Holder M, Billing H, Fischer DC, Rabl W, Schumacher M, Hiort O, Haffner D, Hypophosphatemic Rickets Study Group of the Arbeitsgemeinschaft fur Padiatrische Endokrinologie and Gesellschaft fur Padiatrische Nephrologie (2011) Three-year growth hormone treatment in short children with X-linked hypophosphatemic rickets: effects on linear growth and body disproportion. J Clin Endocrinol Metab 96:2097

51. Hirschberg R, Ding H, Wanner C (1995) Effects of insulin-like growth factor I on phosphate transport in cultured proximal tubule cells. J Lab Clin Med 126:428-434

52. Jehle AW, Forgo J, Biber J, Lederer E, Krapf R, Murer H (1998) IGF-I and vanadate stimulate na/pi-cotransport in OK cells by increasing type II na/pi-cotransporter protein stability. Pflugers Arch 437:149-154

53. Quigley R, Baum M (1991) Effects of growth hormone and insulin-like growth factor I on rabbit proximal convoluted tubule transport. J Clin Invest 88:368-374

54. Meinhardt U, Nelson AE, Hansen JL, Birzniece V, Clifford D, Leung KC, Graham K, Ho KK (2010) The effects of growth hormone on body composition and physical performance in recreational athletes: a randomized trial. Ann Intern Med 152:568577

55. Beck JC, McGarry EE, Dyrenfurth I, Venning EH (1957) Metabolic effects of human and monkey growth hormone in man. Science 125:884-885

56. Møller J (2003) Effects of growth hormone on fluid homeostasis. clinical and experimental aspects. Growth Hormon IGF Res 13: 55-74

57. Hansen TK, Møller J, Thomsen K, Frandsen E, Dall R, Jørgensen JO, Christiansen JS (2001) Effects of growth hormone on renal tubular handling of sodium in healthy humans. Am J Physiol Endocrinol Metab 281:E1326-E1332

58. Johannsson G, Gibney J, Wolthers T, Leung KC, Ho KK (2005) Independent and combined effects of testosterone and growth hormone on extracellular water in hypopituitary men. J Clin Endocrinol Metab 90:3989-3994

59. Møller J, Jørgensen JO, Marqversen J, Frandsen E, Christiansen JS (2000) Insulin-like growth factor I administration induces fluid and sodium retention in healthy adults: possible involvement of renin and atrial natriuretic factor. Clin Endocrinol 52:181-186

60. Walker JL, Ginalska-Malinowska M, Romer TE, Pucilowska JB, Underwood LE (1991) Effects of the infusion of insulin-like growth factor I in a child with growth hormone insensitivity syndrome (laron dwarfism). N Engl J Med 324:1483-1488

61. Blazer-Yost BL, Cox M, Furlanetto R (1989) Insulin and IGF I receptor-mediated na+ transport in toad urinary bladders. Am $\mathrm{J}$ Phys 257:C612-C620

62. Kamenicky P, Blanchard A, Frank M, Salenave S, Letierce A, Azizi M, Lombès M, Chanson P (2011) Body fluid expansion in acromegaly is related to enhanced epithelial sodium channel (ENaC) activity. J Clin Endocrinol Metab 96:2127-2135

63. Viengchareun S, Kamenicky P, Teixeira M, Butlen D, Meduri G, Blanchard-Gutton N, Kurschat C, Lanel A, Martinerie L, SztalMazer S, Blot-Chabaud M, Ferrary E, Cherradi N, Lombès M (2009) Osmotic stress regulates mineralocorticoid receptor expression in a novel aldosterone-sensitive cortical collecting duct cell line. Mol Endocrinol 23:1948-1962

64. Marcus R, Butterfield G, Holloway L, Gilliland L, Baylink DJ, Hintz RL, Sherman BM (1990) Effects of short term administration of recombinant human growth hormone to elderly people. J Clin Endocrinol Metab 70:519-527

65. Bianda T, Hussain MA, Glatz Y, Bouillon R, Froesch ER, Schmid C (1997) Effects of short-term insulin-like growth factor-I or growth hormone treatment on bone turnover, renal phosphate reabsorption and 1,25 dihydroxyvitamin D3 production in healthy man. J Intern Med 241:143-150

66. Nesbitt T, Drezner MK (1993) Insulin-like growth factor-I regulation of renal 25-hydroxyvitamin D-1-hydroxylase activity. Endocrinology 132:133-138

67. Menaa C, Vrtovsnik F, Friedlander G, Corvol M, Garabédian M (1995) Insulin-like growth factor I, a unique calcium-dependent stimulator of 1,25-dihydroxyvitamin D3 production. studies in cultured mouse kidney cells. J Biol Chem 270:25461-25467

68. Wei S, Tanaka H, Seino Y (1998) Local action of exogenous growth hormone and insulin-like growth factor-I on dihydroxyvitamin D production in LLC-PK1 cells. Eur J Endocrinol 139:454-460

69. Christakos S, Veldurthy V, Patel N, Wei R (2017) Intestinal regulation of calcium: vitamin D and bone physiology. Adv Exp Med Biol 1033:3-12

70. Ishizawa M, Akagi D, Yamamoto J, Makishima M (2017) $1 \alpha, 25$ dihydroxyvitamin $\mathrm{D}(3)$ enhances TRPV6 transcription through p38 MAPK activation and GADD45 expression. J Steroid Biochem Mol Biol 172:55-61

71. Hoenderop JG, Müller D, Van Der Kemp AW, Hartog A, Suzuki M, Ishibashi K, Imai M, Sweep F, Willems PH, Van Os CH, Bindels RJ (2001) Calcitriol controls the epithelial calcium channel in kidney. J Am Soc Nephrol 12:1342-1349

72. Kamenický P, Blanchard A, Gauci C, Salenave S, Letierce A, Lombès M, Brailly-Tabard S, Azizi M, Prié D, Souberbielle JC, Chanson P (2012) Pathophysiology of renal calcium handling in acromegaly: what lies behind hypercalciuria? J Clin Endocrinol Metab 97:2124-2133

73. Haussler MR, Whitfield GK, Kaneko I, Haussler CA, Hsieh D, Hsieh JC, Jurutka PW (2013) Molecular mechanisms of vitamin D action. Calcif Tissue Int 92:77-98

74. Glaser NS, Shirali AC, Styne DM, Jones KL (1998) Acid-base homeostasis in children with growth hormone deficiency. Pediatrics 102:1407-1414

75. Welbourne TC, Cronin MJ (1991) Growth hormone accelerates tubular acid secretion. Am J Phys 260:R1036-R1042

76. Chobanian MC, Julin CM, Molteni KH, Brazy PC (1992) Growth hormone regulates ammoniagenesis in canine renal proximal tubule segments. Am J Phys 262:F878-F884

77. Jehle S, Hulter HN, Krapf R (2000) On the mechanism of growth hormone-induced stimulation of renal acidification in humans: effect of dietary $\mathrm{NaCl}$. Clin Sci (Lond) 99:47-56 
78. Legouis D, Faivre A, Cippà PE, de Seigneux S (2020) Renal gluconeogenesis: an underestimated role of the kidney in systemic glucose metabolism. Nephrol Dial Transplant. https://doi.org/10. 1093/ndt/gfaa302

79. Rogers SA, Karl IE, Hammerman MR (1989) Growth hormone directly stimulates gluconeogenesis in canine renal proximal tubule. Am J Phys 257:E751-E756

80. Neyra JA, Hu MC, Moe OW (2020) Klotho in clinical nephrology: diagnostic and therapeutic implications. Clin J Am Soc Nephrol 16:162-176

81. Erben RG (2018) Physiological actions of fibroblast growth factor-23. Front Endocrinol (Lausanne) 9:267

82. Bi X, Yang K, Zhang B, Zhao J (2020) The protective role of klotho in CKD-associated cardiovascular disease. Kidney Dis (Basel) 6:395-406

83. Adema AY, de Roij van Zuijdewijn CLM, Hoenderop JG, de Borst MH, Ter Wee PM, Heijboer AC, Vervloet MG, NIGRAM consortium (2018) Influence of exogenous growth hormone administration on circulating concentrations of $\alpha$-klotho in healthy and chronic kidney disease subjects: a prospective, single-center open case-control pilot study. BMC Nephrol 19:327-z

84. Locher R, Egger A, Zwimpfer C, Sze L, Schmid C, Christ E (2015) Effect of growth hormone replacement therapy on soluble klotho in patients with growth hormone deficiency. Clin Endocrinol 83:593-595

85. Ewert A, Leifheit-Nestler M, Hohenfellner K, Büscher A, Kemper MJ, Oh J, Billing H, Thumfart J, Stangl G, Baur AC, Föller M, Feger M, Weber LT, Acham-Roschitz B, Arbeiter K, Tönshoff B, Zivicnjak M, Haffner D (2020) Bone and mineral metabolism in children with nephropathic cystinosis compared with other CKD entities. J Clin Endocrinol Metab 105:dgaa267. https://doi.org/10. 1210/clinem/dgaa267

86. Haffner D, Leifheit-Nestler M (2017) Extrarenal effects of FGF23. Pediatr Nephrol 32:753-765

87. Shahmoon S, Rubinfeld H, Wolf I, Cohen ZR, Hadani M, Shimon I, Rubinek T (2014) The aging suppressor klotho: a potential regulator of growth hormone secretion. Am J Physiol Endocrinol Metab 307:E326-E334

88. Wolf I, Shahmoon S, Ben Ami M, Levy-Shraga Y, MazorAronovitch K, Pinhas-Hamiel O, Yeshayahu Y, Hemi R, Kanety H, Rubinek T, Modan-Moses D (2014) Association between decreased klotho blood levels and organic growth hormone deficiency in children with growth impairment. PLoS One 9: e107174

89. Kasuki L, Antunes X, Lamback EB, Gadelha MR (2020) Acromegaly: update on management and long-term morbidities. Endocrinol Metab Clin N Am 49:475-486

90. Auriemma RS, Galdiero M, De Martino MC, De Leo M, Grasso LF, Vitale P, Cozzolino A, Lombardi G, Colao A, Pivonello R (2010) The kidney in acromegaly: renal structure and function in patients with acromegaly during active disease and 1 year after disease remission. Eur J Endocrinol 162:1035-1042

91. Zhang Z, Li Q, He W, Qiu H, Ye H, Wang Y, Shen M, He M, Yu Y, Shou X, Huang C, Yu H, Huang G, Tang W, Geng D, Fu C, Liu C, Ma Z, Ye Z, Zhang Q, Zhang Y, Shen Y, Yang Y, Wang M, Liu X, Lu Y, Hu R, Mao Y, Zhou L, Li Y, Li S, Tritos NA, Zhao Y (2018) The comprehensive impact on human body induced by resolution of growth hormone excess. Eur J Endocrinol 178:365-375

92. Takai M, Izumino K, Oda Y, Terada Y, Inoue H, Takata M (2001) Focal segmental glomerulosclerosis associated with acromegaly. Clin Nephrol 56:75-77

93. Yoshida H, Akikusa B, Saeki N, Hasegawa S, Iesato K, Yamamoto S, Murotani N, Wakashin M, Shimada T (1999) Effect of pituitary microsurgery on acromegaly complicated nephrotic syndrome with focal segmental glomerulosclerosis: Report of a rare clinical case. Am J Kidney Dis 33:1158-1163

94. Wang R, Wu Y, An D, Ma P, Guo Y, Tang L (2021) Case report: glucocorticoids combined with immunosuppressant in the treatment of acromegaly complicated with focal segmental glomerulosclerosis. Front Med (Lausanne) 7:563020

95. Timsit J, Riou B, Bertherat J, Wisnewsky C, Kato NS, Weisberg AS, Lubetzki J, Lecarpentier Y, Winegrad S, Mercadier JJ (1990) Effects of chronic growth hormone hypersecretion on intrinsic contractility, energetics, isomyosin pattern, and myosin adenosine triphosphatase activity of rat left ventricle. J Clin Invest 86:507515

96. Fujio S, Takano K, Arimura H, Habu M, Bohara M, Hirano H, Hanaya R, Nishio Y, Koriyama C, Kinoshita Y, Arita K (2016) Treatable glomerular hyperfiltration in patients with active acromegaly. Eur J Endocrinol 175:325-333

97. Hoogenberg K, Sluiter WJ, Dullaart RP (1993) Effect of growth hormone and insulin-like growth factor I on urinary albumin excretion: studies in acromegaly and growth hormone deficiency. Acta Endocrinol 129:151-157

98. Grunenwald S, Tack I, Chauveau D, Bennet A, Caron P (2011) Impact of growth hormone hypersecretion on the adult human kidney. Ann Endocrinol (Paris) 72:485-495

99. Baldelli R, De Marinis L, Bianchi A, Pivonello R, Gasco V, Auriemma R, Pasimeni G, Cimino V, Appetecchia M, Maccario M, Lombardi G, Pontecorvi A, Colao A, Grottoli S (2008) Microalbuminuria in insulin sensitivity in patients with growth hormone-secreting pituitary tumor. J Clin Endocrinol Metab 93: 710-714

100. Kamenický P, Maione L, Chanson P (2020) Cardiovascular complications of acromegaly. Ann Endocrinol (Paris) 18:S00034266(20)30045-7. https://doi.org/10.1016/j.ando.2020.03.010

101. Ikkos D, Luft R, Sjogren B (1954) Body water and sodium in patients with acromegaly. J Clin Invest 33:989-994

102. Deray G, Rieu M, Devynck MA, Pernollet MG, Chanson P, Luton JP, Meyer P (1987) Evidence of an endogenous digitalis-like factor in the plasma of patients with acromegaly. N Engl J Med 316: 575-580

103. Strauch G, Vallotton MB, Touitou Y, Bricaire H (1972) The renin-angiotensin-aldosterone system in normotensive and hypertensive patients with acromegaly. N Engl J Med 287:795-799

104. Hirsch EZ, Sloman JG, Martin FI (1969) Cardiac function in acromegaly. Am J Med Sci 257:1-8

105. Vila G, Luger A, van der Lely AJ, Neggers SJCMM, Webb SM, Biller BMK, Valluri S, Hey-Hadavi J (2020) Hypertension in acromegaly in relationship to biochemical control and mortality: global ACROSTUDY outcomes. Front Endocrinol (Lausanne) 11:577173

106. Nemes A, Kormányos Á, Domsik P, Kalapos A, Gyenes N, Lengyel C, Valkusz Z (2021) Diabetes mellitus deteriorates left ventricular deformation in acromegaly-analysis from the threedimensional speckle-tracking echocardiographic MAGYARpath study. Quant Imaging Med Surg 11:410-414

107. Xie T, Tian P, Wu S, Zhang X, Liu T, Gu Y, Sun C, Hu F (2020) Serum phosphate: does it more closely reflect the true state of acromegaly? J Clin Neurosci 71:26-31

108. Manroa P, Kannan S, Hatipoglu B, Licata A (2014) Hypercalcemia and acromegaly-clarifying the connections. A case report and review of the literature. Endocr Pract 20:86

109. Suzuki Y, Landowski CP, Hediger MA (2008) Mechanisms and regulation of epithelial $\mathrm{Ca} 2+$ absorption in health and disease. Annu Rev Physiol 70:257-271

110. Mazziotti G, Bianchi A, Porcelli T, Mormando M, Maffezzoni F, Cristiano A, Giampietro A, De Marinis L, Giustina A (2013) Vertebral fractures in patients with acromegaly: a 3-year prospective study. J Clin Endocrinol Metab 98:3402-3410 
111. Sze L, Bernays RL, Zwimpfer C, Wiesli P, Brändle M, Schmid C (2012) Excessively high soluble klotho in patients with acromegaly. J Intern Med 272:93-97

112. Schmid C, Neidert MC, Tschopp O, Sze L, Bernays RL (2013) Growth hormone and klotho. J Endocrinol 219:R37-R57

113. Rubinek T, Modan-Moses D (2016) Klotho and the growth hormone/insulin-like growth factor 1 axis: novel insights into complex interactions. Vitam Horm 101:85-118

114. Pesce CM, Striker LJ, Peten E, Elliot SJ, Striker GE (1991) Glomerulosclerosis at both early and late stages is associated with increased cell turnover in mice transgenic for growth hormone. Lab Investig 65:601-605

115. Machado MO, Hirata RD, Sellitti DF, Iotti R, Iotti A, Cusumano AM, Riordan GP, Coschigano KT, Kopchick JJ, Zuhl I, Nguyen N, Hirata MH, Doi SQ (2005) Growth hormone promotes glomerular lipid accumulation in bGH mice. Kidney Int 68:2019-2028

116. Striker LJ, Doi T, Striker GE (1991) Transgenic mice in renal research. Adv Nephrol Necker Hosp 20:91-108

117. Doi T, Striker LJ, Kimata K, Peten EP, Yamada Y, Striker GE (1991) Glomerulosclerosis in mice transgenic for growth hormone. increased mesangial extracellular matrix is correlated with kidney mRNA levels. J Exp Med 173:1287-1290

118. Yang CW, Striker LJ, Pesce C, Chen WY, Peten EP, Elliot S, Doi T, Kopchick JJ, Striker GE (1993) Glomerulosclerosis and body growth are mediated by different portions of bovine growth hormone. studies in transgenic mice. Lab Investig 68:62-70

119. Kopchick JJ, Bellush LL, Coschigano KT (1999) Transgenic models of growth hormone action. Annu Rev Nutr 19:437-461

120. Doi T, Striker LJ, Quaife C, Conti FG, Palmiter R, Behringer R, Brinster R, Striker GE (1988) Progressive glomerulosclerosis develops in transgenic mice chronically expressing growth hormone and growth hormone releasing factor but not in those expressing insulinlike growth factor-1. Am J Pathol 131:398-403

121. Doi T, Striker LJ, Gibson CC, Agodoa LY, Brinster RL, Striker GE (1990) Glomerular lesions in mice transgenic for growth hormone and insulinlike growth factor-I. I. relationship between increased glomerular size and mesangial sclerosis. Am J Pathol 137: 541-552

122. Blutke A, Schneider MR, Renner-Müller I, Herbach N, Wanke R, Wolf E (2014) Genetic dissection of IGF1-dependent and independent effects of permanent GH excess on postnatal growth and organ pathology of mice. Mol Cell Endocrinol 394:88-98

123. Blutke A, Schneider MR, Wolf E, Wanke R (2016) Growth hormone (GH)-transgenic insulin-like growth factor 1 (IGF1)-deficient mice allow dissociation of excess GH and IGF1 effects on glomerular and tubular growth. Phys Rep 4:e12709. https://doi. org/10.14814/phy2.12709

124. Ritz E, Tönshoff B, Worgall S, Kovacs G, Mehls O (1991) Influence of growth hormone and insulin-like growth factor-I on kidney function and kidney growth. Pediatr Nephrol 5:509-512

125. Moerth C, Schneider MR, Renner-Mueller I, Blutke A, Elmlinger MW, Erben RG, Camacho-Hübner C, Hoeflich A, Wolf E (2007) Postnatally elevated levels of insulin-like growth factor (IGF)-II fail to rescue the dwarfism of IGF-I-deficient mice except kidney weight. Endocrinology 148:441-451

126. Liu JP, Baker J, Perkins AS, Robertson EJ, Efstratiadis A (1993) Mice carrying null mutations of the genes encoding insulin-like growth factor I (igf-1) and type 1 IGF receptor (Igflr). Cell 75:5972

127. Woods KA, Camacho-Hübner C, Savage MO, Clark AJ (1996) Intrauterine growth retardation and postnatal growth failure associated with deletion of the insulin-like growth factor I gene. N Engl J Med 335:1363-1367

128. Amselem S, Duquesnoy P, Attree O, Novelli G, Bousnina S, Postel-Vinay MC, Goossens M (1989) Laron dwarfism and mutations of the growth hormone-receptor gene. N Engl J Med 321:989-995

129. Goossens M, Brauner R, Czernichow P, Duquesnoy P, Rappaport $\mathrm{R}$ (1986) Isolated growth hormone (GH) deficiency type 1A associated with a double deletion in the human GH gene cluster. $\mathrm{J}$ Clin Endocrinol Metab 62:712-716

130. Falkheden T, Sjoegren B (1964) Extracellular fluid volume and renal function in pituitary insufficiency and acromegaly. Acta Endocrinol 46:80-88

131. Link K, Bülow B, Westman K, Salmonsson EC, Eskilsson J, Erfurth EM (2001) Low individualized growth hormone (GH) dose increased renal and cardiac growth in young adults with childhood onset GH deficiency. Clin Endocrinol 55:741-748

132. Chernausek SD, Backeljauw PF, Frane J, Kuntze J, Underwood LE, GH Insensitivity Syndrome Collaborative Group (2007) Long-term treatment with recombinant insulin-like growth factor (IGF)-I in children with severe IGF-I deficiency due to growth hormone insensitivity. J Clin Endocrinol Metab 92:902-910

133. Klinger B, Laron Z (1994) Renal function in laron syndrome patients treated by insulin-like growth factor-I. Pediatr Nephrol 8 : 684-688

134. Caidahl K, Edén S, Bengtsson BA (1994) Cardiovascular and renal effects of growth hormone. Clin Endocrinol 40:393-400

135. Jørgensen JO, Pedersen SA, Thuesen L, Jørgensen J, IngemannHansen T, Skakkebaek NE, Christiansen JS (1989) Beneficial effects of growth hormone treatment in GH-deficient adults. Lancet 1:1221-1225

136. Hoffman DM, Crampton L, Sernia C, Nguyen TV, Ho KK (1996) Short-term growth hormone (GH) treatment of GH-deficient adults increases body sodium and extracellular water, but not blood pressure. J Clin Endocrinol Metab 81:1123-1128

137. de Boer H, Blok GJ, Van der Veen EA (1995) Clinical aspects of growth hormone deficiency in adults. Endocr Rev 16:63-86

138. Jørgensen JO (1991) Human growth hormone replacement therapy: pharmacological and clinical aspects. Endocr Rev 12:189-207

139. Boguszewski MCS (2021) Growth hormone deficiency and replacement in children. Rev Endocr Metab Disord 22:101-108. https://doi.org/10.1007/s11154-020-09604-2

140. Bengtsson BA, Edén S, Lönn L, Kvist H, Stokland A, Lindstedt G, Bosaeus I, Tölli J, Sjöström L, Isaksson OG (1993) Treatment of adults with growth hormone (GH) deficiency with recombinant human GH. J Clin Endocrinol Metab 76:309-317

141. Beshyah SA, Kyd P, Thomas E, Fairney A, Johnston DG (1995) The effects of prolonged growth hormone replacement on bone metabolism and bone mineral density in hypopituitary adults. Clin Endocrinol 42:249-254

142. Beshyah SA, Thomas E, Kyd P, Sharp P, Fairney A, Johnston DG (1994) The effect of growth hormone replacement therapy in hypopituitary adults on calcium and bone metabolism. Clin Endocrinol 40:383-391

143. Hansen TB, Brixen K, Vahl N, Jørgensen JO, Christiansen JS, Mosekilde L, Hagen C (1996) Effects of 12 months of growth hormone (GH) treatment on calciotropic hormones, calcium homeostasis, and bone metabolism in adults with acquired GH deficiency: a double blind, randomized, placebo-controlled study. J Clin Endocrinol Metab 81:3352-3359

144. Vaccarello MA, Diamond FB Jr, Guevara-Aguirre J, Rosenbloom AL, Fielder PJ, Gargosky S, Cohen P, Wilson K, Rosenfeld RG (1993) Hormonal and metabolic effects and pharmacokinetics of recombinant insulin-like growth factor-I in growth hormone receptor deficiency/laron syndrome. J Clin Endocrinol Metab 77: 273-280

145. Bianda T, Glatz Y, Bouillon R, Froesch ER, Schmid C (1998) Effects of short-term insulin-like growth factor-I (IGF-I) or growth hormone $(\mathrm{GH})$ treatment on bone metabolism and on production 
of 1,25-dihydroxycholecalciferol in GH-deficient adults. J Clin Endocrinol Metab 83:81-87

146. Wei S, Tanaka H, Kubo T, Ono T, Kanzaki S, Seino Y (1997) Growth hormone increases serum 1,25-dihydroxyvitamin D levels and decreases 24,25-dihydroxyvitamin D levels in children with growth hormone deficiency. Eur J Endocrinol 136:45-51

147. Mauras N, O'Brien KO, Welch S, Rini A, Helgeson K, Vieira NE, Yergey AL (2000) Insulin-like growth factor I and growth hormone $(\mathrm{GH})$ treatment in GH-deficient humans: differential effects on protein, glucose, lipid, and calcium metabolism. J Clin Endocrinol Metab 85:1686-1694

148. Boot AM, Engels MA, Boerma GJ, Krenning EP, De Muinck Keizer-Schrama SM (1997) Changes in bone mineral density, body composition, and lipid metabolism during growth hormone (GH) treatment in children with GH deficiency. J Clin Endocrinol Metab 82:2423-2428

149. Saggese G, Baroncelli GI, Bertelloni S, Cinquanta L, Di Nero G (1993) Effects of long-term treatment with growth hormone on bone and mineral metabolism in children with growth hormone deficiency. J Pediatr 122:37-45

150. McArdle Z, Schreuder MF, Moritz KM, Denton KM, Singh RR (2020) Physiology and pathophysiology of compensatory adaptations of a solitary functioning kidney. Front Physiol 11:725

151. Ece A, Çetinkaya S, Ekșioğlu S, Șenel S, Özkasap S, Giniș T, Sen V, Sahin C (2014) Kidney growth and renal functions under the growth hormone replacement therapy in children. Ren Fail 36: 508-513

152. Mulroney SE, Lumpkin MD, Roberts CT Jr, LeRoith D, Haramati A (1992) Effect of a growth hormone-releasing factor antagonist on compensatory renal growth, insulin-like growth factor-I (GFI), and IGF-I receptor gene expression after unilateral nephrectomy in immature rats. Endocrinology 130:2697-2702

153. Mulroney SE, Haramati A, Werner H, Bondy C, Roberts CT Jr, LeRoith D (1992) Altered expression of insulin-like growth factor-I (IGF-I) and IGF receptor genes after unilateral nephrectomy in immature rats. Endocrinology 130:249-256

154. Drube J, Wan M, Bonthuis M, Wühl E, Bacchetta J, Santos F, Grenda R, Edefonti A, Harambat J, Shroff R, Tönshoff B, Haffner D, European Society for Paediatric Nephrology Chronic Kidney Disease Mineral and Bone Disorders, Dialysis, and Transplantation Working Groups (2019) Clinical practice recommendations for growth hormone treatment in children with chronic kidney disease. Nat Rev Nephrol 15:577-589

155. Schaefer F, Baumann G, Haffner D, Faunt LM, Johnson ML, Mercado M, Ritz E, Mehls O, Veldhuis JD (1996) Multifactorial control of the elimination kinetics of unbound (free) growth hormone $(\mathrm{GH})$ in the human: regulation by age, adiposity, renal function, and steady state concentrations of GH in plasma. J Clin Endocrinol Metab 81:22-31

156. Rabkin R, Sun DF, Chen Y, Tan J, Schaefer F (2005) Growth hormone resistance in uremia, a role for impaired JAK/STAT signaling. Pediatr Nephrol 20:313-318

157. Schaefer F, Chen Y, Tsao T, Nouri P, Rabkin R (2001) Impaired JAK-STAT signal transduction contributes to growth hormone resistance in chronic uremia. J Clin Invest 108:467-475

158. Postel-Vinay MC, Tar A, Crosnier H, Broyer M, Rappaport R, Tonshoff B, Mehls O (1991) Plasma growth hormone-binding activity is low in uraemic children. Pediatr Nephrol 5:545-547

159. Bach LA, Hale LJ (2015) Insulin-like growth factors and kidney disease. Am J Kidney Dis 65:327-336

160. Kiepe D, Tonshoff B (2012) Insulin-like growth factors in normal and diseased kidney. Endocrinol Metab Clin N Am 41(351-74):vii

161. Powell DR, Durham SK, Liu F, Baker BK, Lee PD, Watkins SL, Campbell PG, Brewer ED, Hintz RL, Hogg RJ (1998) The insulinlike growth factor axis and growth in children with chronic renal failure: a report of the southwest pediatric nephrology study group. J Clin Endocrinol Metab 83:1654-1661

162. Ding H, Gao XL, Hirschberg R, Vadgama JV, Kopple JD (1996) Impaired actions of insulin-like growth factor 1 on protein synthesis and degradation in skeletal muscle of rats with chronic renal failure. evidence for a postreceptor defect. J Clin Invest 97:1064 1075

163. Rees L (2016) Growth hormone therapy in children with CKD after more than two decades of practice. Pediatr Nephrol 31: 1421-1435

164. Miller SB, Hansen VA, Hammerman MR (1990) Effects of growth hormone and IGF-I on renal function in rats with normal and reduced renal mass. Am J Phys 259:F747-F751

165. Nakano M, Kainer G, Foreman JW, Ko DJ, Chan JC (1989) The effects of exogenous rat growth hormone therapy on growth of uremic rats fed an 8\% protein diet. Pediatr Res 26:204-207

166. Allen DB, Fogo A, El-Hayek R, Langhough R, Friedman AL (1992) Effects of prolonged growth hormone administration in rats with chronic renal insufficiency. Pediatr Res 31:406-410

167. Kawaguchi H, Hattori M, Ito K (1997) Somatic and renal effects of growth hormone in rats with chronic renal failure. Pediatr Nephrol 11:280-284

168. Tönshoff B, Heinrich U, Mehls O (1991) How safe is the treatment of uraemic children with recombinant human growth hormone? Pediatr Nephrol 5:454-460

169. Maxwell H, Nair DR, Dalton RN, Rigden SP, Rees L (1995) Differential effects of recombinant human growth hormone on glomerular filtration rate and renal plasma flow in chronic renal failure. Pediatr Nephrol 9:458-463

170. Maxwell H, Dalton RN, Nair DR, Turner C, Saunders AJ, Rigden SP, Rees L (1996) Effects of recombinant human growth hormone on renal function in children with renal transplants. J Pediatr 128: 177-183

171. Hodson EM, Willis NS, Craig JC (2012) Growth hormone for children with chronic kidney disease. Cochrane Database Syst Rev 2:CD003264 https://doi.org/CD003264

172. Wuhl E, Haffner D, Gretz N, Offner G, van't Hoff WG, Broyer M, Mehls O (1998) Treatment with recombinant human growth hormone in short children with nephropathic cystinosis: no evidence for increased deterioration rate of renal function. The European study group on growth hormone treatment in short children with nephropathic cystinosis. Pediatr Res 43:484-488

173. Mehls O, Lindberg A, Haffner D, Schaefer F, Wühl E, German KIGS Board, ESCAPE Trial Group (2015) Long-term growth hormone treatment in short children with CKD does not accelerate decline of renal function: results from the KIGS registry and ESCAPE trial. Pediatr Nephrol 30:2145-2151

174. Landau D, Assadi MH, Abu Hilal R, Chen Y, Rabkin R, Segev Y (2020) SOCS2 silencing improves somatic growth without worsening kidney function in CKD. Am J Nephrol 51:520-526

175. Wu Y, Cheng W, Yang XD, Xiang B (2013) Growth hormone improves growth in pediatric renal transplant recipients - a systemic review and meta-analysis of randomized controlled trials. Pediatr Nephrol 28:129-133

176. O'Shea MH, Miller SB, Hammerman MR (1993) Effects of IGF-I on renal function in patients with chronic renal failure. Am J Phys 264:F917-F922

177. Miller SB, Moulton M, O'Shea M, Hammerman MR (1994) Effects of IGF-I on renal function in end-stage chronic renal failure. Kidney Int 46:201-207

178. Vijayan A, Franklin SC, Behrend T, Hammerman MR, Miller SB (1999) Insulin-like growth factor I improves renal function in patients with end-stage chronic renal failure. Am J Phys 276:R929R934 
179. Wen Y, Yang C, Menez SP, Rosenberg AZ, Parikh CR (2020) A systematic review of clinical characteristics and histologic descriptions of acute tubular injury. Kidney Int Rep 5:1993-2001

180. Miller SB, Martin DR, Kissane J, Hammerman MR (1992) Insulin-like growth factor I accelerates recovery from ischemic acute tubular necrosis in the rat. Proc Natl Acad Sci U S A 89: 11876-11880

181. Goes N, Urmson J, Vincent D, Ramassar V, Halloran PF (1996) Effect of recombinant human insulin-like growth factor-1 on the inflammatory response to acute renal injury. J Am Soc Nephrol 7: 710-720

182. Friedlaender M, Popovtzer MM, Weiss O, Nefesh I, Kopolovic J, Raz I (1995) Insulin-like growth factor-1 (IGF-1) enhances recovery from $\mathrm{HgCl} 2$-induced acute renal failure: the effects on renal IGF-1, IGF-1 receptor, and IGF-binding protein-1 mRNA. J Am Soc Nephrol 5:1782-1791

183. Ding H, Kopple JD, Cohen A, Hirschberg R (1993) Recombinant human insulin-like growth factor-I accelerates recovery and reduces catabolism in rats with ischemic acute renal failure. $\mathrm{J}$ Clin Invest 91:2281-2287

184. Matejka GL, Bengtsson BA (1998) High dosage growth hormone treatment and post-ischemic acute renal failure in the rat. Growth Hormon IGF Res 8:151-157

185. Franklin SC, Moulton M, Sicard GA, Hammerman MR, Miller SB (1997) Insulin-like growth factor I preserves renal function postoperatively. Am J Phys 272:F257-F259

186. Kumar PA, Brosius FC 3rd, Menon RK (2011) The glomerular podocyte as a target of growth hormone action: implications for the pathogenesis of diabetic nephropathy. Curr Diabetes Rev 7: 50-55

187. Mukhi D, Nishad R, Menon RK, Pasupulati AK (2017) Novel actions of growth hormone in podocytes: implications for diabetic nephropathy. Front Med (Lausanne) 4:102

188. Menon RK, Stephan DA, Rao RH, Shen-Orr Z, Downs LS Jr, Roberts CT Jr, LeRoith D, Sperling MA (1994) Tissue-specific regulation of the growth hormone receptor gene in streptozocininduced diabetes in the rat. J Endocrinol 142:453-462

189. Yakar S, Setser J, Zhao H, Stannard B, Haluzik M, Glatt V, Bouxsein ML, Kopchick JJ, LeRoith D (2004) Inhibition of growth hormone action improves insulin sensitivity in liver IGF1-deficient mice. J Clin Invest 113:96-105

190. Brismar K, Gutniak M, Povoa G, Werner S, Hall K (1988) Insulin regulates the $35 \mathrm{kDa}$ IGF binding protein in patients with diabetes mellitus. J Endocrinol Investig 11:599-602

191. Salgado LR, Semer M, Nery M, Knoepfelmacher M, Lerário AC, Póvoa G, Jana S, Villares SM, Wajchenberg BL, Liberman B, Nicolau W (1996) Effect of glycemic control on growth hormone and IGFBP-1 secretion in patients with type I diabetes mellitus. J Endocrinol Investig 19:433-440

192. Muñoz MT, Barrios V, Pozo J, Argente J (1996) Insulin-like growth factor I, its binding proteins 1 and 3, and growth hormone-binding protein in children and adolescents with insulin-dependent diabetes mellitus: clinical implications. Pediatr Res 39:992-998

193. Tuttle KR, Bruton JL, Perusek MC, Lancaster JL, Kopp DT, DeFronzo RA (1991) Effect of strict glycemic control on renal hemodynamic response to amino acids and renal enlargement in insulin-dependent diabetes mellitus. N Engl J Med 324:16261632

194. Bank N (1991) Mechanisms of diabetic hyperfiltration. Kidney Int 40:792-807

195. Chitra PS, Swathi T, Sahay R, Reddy GB, Menon RK, Kumar PA (2015) Growth hormone induces transforming growth factor-betainduced protein in podocytes: implications for podocyte depletion and proteinuria. J Cell Biochem 116:1947-1956
196. Aaltonen P, Luimula P, Aström E, Palmen T, Grönholm T, Palojoki E, Jaakkola I, Ahola H, Tikkanen I, Holthöfer H (2001) Changes in the expression of nephrin gene and protein in experimental diabetic nephropathy. Lab Investig 81:1185-1190

197. Verzola D, Gandolfo MT, Ferrario F, Rastaldi MP, Villaggio B, Gianiorio F, Giannoni M, Rimoldi L, Lauria F, Miji M, Deferrari G, Garibotto G (2007) Apoptosis in the kidneys of patients with type II diabetic nephropathy. Kidney Int 72:1262-1272

198. Wolf G, Chen S, Ziyadeh FN (2005) From the periphery of the glomerular capillary wall toward the center of disease: podocyte injury comes of age in diabetic nephropathy. Diabetes 54:1626 1634

199. Orskov H (1996) Somatostatin, growth hormone, insulin-like growth factor-1, and diabetes: friends or foes? Metabolism 45: 91-95

200. Verrotti A, Cieri F, Petitti MT, Morgese G, Chiarelli F (1999) Growth hormone and IGF-I in diabetic children with and without microalbuminuria. Diabetes Nutr Metab 12:271-276

201. Cummings EA, Sochett EB, Dekker MG, Lawson ML, Daneman D (1998) Contribution of growth hormone and IGF-I to early diabetic nephropathy in type 1 diabetes. Diabetes 47:1341-1346

202. Landau D, Domene H, Flyvbjerg A, Grønbaek H, Roberts CT Jr, Argov S, LeRoith D (1998) Differential expression of renal growth hormone receptor and its binding protein in experimental diabetes mellitus. Growth Hormon IGF Res 8:39-45

203. Flyvbjerg A, Bennett WF, Rasch R, Kopchick JJ, Scarlett JA (1999) Inhibitory effect of a growth hormone receptor antagonist (G120K-PEG) on renal enlargement, glomerular hypertrophy, and urinary albumin excretion in experimental diabetes in mice. Diabetes 48:377-382

204. Segev Y, Landau D, Marbach M, Shehadeh N, Flyvbjerg A, Phillip M (1997) Renal hypertrophy in hyperglycemic nonobese diabetic mice is associated with persistent renal accumulation of insulin-like growth factor I. J Am Soc Nephrol 8:436-444

205. Park IS, Kiyomoto H, Alvarez F, Xu YC, Abboud HE, Abboud SL (1998) Preferential expression of insulin-like growth factor binding proteins- $1,-3$, and -5 during early diabetic renal hypertrophy in rats. Am J Kidney Dis 32:1000-1010

206. Isshiki K, He Z, Maeno Y, Ma RC, Yasuda Y, Kuroki T, White GS, Patti ME, Weir GC, King GL (2008) Insulin regulates SOCS2 expression and the mitogenic effect of IGF-1 in mesangial cells. Kidney Int 74:1434-1443

207. Flyvbjerg A, Frystyk J, Thorlacius-Ussing O, Orskov H (1989) Somatostatin analogue administration prevents increase in kidney somatomedin $\mathrm{C}$ and initial renal growth in diabetic and uninephrectomized rats. Diabetologia 32:261-265

208. Chen NY, Chen WY, Kopchick JJ (1997) Liver and kidney growth hormone $(\mathrm{GH})$ receptors are regulated differently in diabetic GH and GH antagonist transgenic mice. Endocrinology 138: 1988-1994

209. Chen NY, Chen WY, Bellush L, Yang CW, Striker LJ, Striker GE, Kopchick JJ (1995) Effects of streptozotocin treatment in growth hormone $(\mathrm{GH})$ and $\mathrm{GH}$ antagonist transgenic mice. Endocrinology 136:660-667

210. Bellush LL, Doublier S, Holland AN, Striker LJ, Striker GE, Kopchick JJ (2000) Protection against diabetes-induced nephropathy in growth hormone receptor/binding protein gene-disrupted mice. Endocrinology 141:163-168

211. Pedersen MM, Christensen SE, Christiansen JS, Pedersen EB, Mogensen CE, Orskov H (1990) Acute effects of a somatostatin analogue on kidney function in type 1 diabetic patients. Diabet Med 7:304-309

212. Serri O, Beauregard H, Brazeau P, Abribat T, Lambert J, Harris A, Vachon L (1991) Somatostatin analogue, octreotide, reduces increased glomerular filtration rate and kidney size in insulindependent diabetes. JAMA 265:888-892 
213. Nishad R, Mukhi D, Tahaseen SV, Mungamuri SK, Pasupulati AK (2019) Growth hormone induces Notch1 signaling in podocytes and contributes to proteinuria in diabetic nephropathy. J Biol Chem 294:16109-16122

214. Mahran YF (2020) New insights into the protection of growth hormone in cisplatin-induced nephrotoxicity: the impact of IGF1 on the Keap1-Nrf2/HO-1 signaling. Life Sci 253:117581

215. Haffner D, Tonshoff B, Blum WF, Vickers M, Siebler T, Cronin MJ, Baxter RC, Mehls O (1997) Insulin-like growth factors (IGFs) and IGF binding proteins, serum acid-labile subunit and growth hormone binding protein in nephrotic children. Kidney Int 52: 802-810

216. Feld SM, Hirschberg R (1996) Insulin-like growth factor-I and insulin-like growth factor-binding proteins in the nephrotic syndrome. Pediatr Nephrol 10:355-358

217. Hirschberg R, Kaysen GA (1995) Insulin-like growth factor I and its binding proteins in the experimental nephrotic syndrome. Endocrinology 136:1565-1571

218. Hirschberg R (1996) Bioactivity of glomerular ultrafiltrate during heavy proteinuria may contribute to renal tubulo-interstitial lesions: evidence for a role for insulin-like growth factor I. J Clin Invest 98:116-124

219. Wang SN, Hirschberg R (1999) Tubular epithelial cell activation and interstitial fibrosis. the role of glomerular ultrafiltration of growth factors in the nephrotic syndrome and diabetic nephropathy. Nephrol Dial Transplant 14:2072-2074
220. Goedegebuure WJ, Kerkhof GF, Hokken-Koelega ACS (2019) Glomerular filtration rate, blood pressure and microalbuminuria in adults born SGA: a 5-year longitudinal study after cessation of GH treatment. Clin Endocrinol 91:892-898

221. Krysiak R, Gdula-Dymek A, Bednarska-Czerwińska A, Okopień B (2007) Growth hormone therapy in children and adults. Pharmacol Rep 59:500-516

222. Rhie YJ, Yoo JH, Choi JH, Chae HW, Kim JH, Chung S, Hwang IT, Shin CH, Kim EY, Kim HS (2019) Long-term safety and effectiveness of growth hormone therapy in Korean children with growth disorders: 5-year results of LG growth study. PLoS One 14:e216927

223. Price DA, Wilton P, Jönsson P, Albertsson-Wikland K, Chatelain P, Cutfield W, Ranke MB (1998) Efficacy and safety of growth hormone treatment in children with prior craniopharyngioma: an analysis of the pharmacia and upjohn international growth database (KIGS) from 1988 to 1996. Horm Res 49:91-97

224. Cutfield WS, Lindberg A, Rapaport R, Wajnrajch MP, Saenger P (2006) Safety of growth hormone treatment in children born small for gestational age: the US trial and KIGS analysis. Horm Res 65(Suppl 3):153-159

Publisher's note Springer Nature remains neutral with regard to jurisdictional claims in published maps and institutional affiliations. 